\title{
HealthCARE CoRporate Structure AND the ACA: A NeEd For Mission PRIMACY THROUGH A NEW ORGANIZATIONAL PARADIGM?
}

\author{
Terry L. Corbett, MHSA, MBA, JD, LLM*
}

\begin{abstract}
$\underline{\text { ABSTRACT }}$
Notwithstanding passage of the Affordable Care Act (ACA) in 2010, the debate over the deontological nature of health care in the United States continues. Reflecting opposing views on the issue, the provision of private (i.e., non-governmental), institutional health care in this country has evolved into a limited, binary choice of organizational forms: that is, nonprofit hospitals provide care ostensibly in order to maximize the public good; for-profit hospitals provide care as a means to maximize owner profit. Over time, however, developments in medical science, technology, and business economics have resulted in increased commercialization of both organizational forms, blurring these traditional distinctions. Increasingly, questions are being raised about the appropriateness of continuing to afford tax-exemption to what may be, in many instances, only nominally "nonprofit" business enterprises.

The ACA is expected to bring a number of systemic changes to the larger health care delivery system in which these organizations operate. Among these changes is a significant increase in the number of Americans with health insurance. This increase will reduce the need for charity care - the primary rationale for the initial development of nonprofit hospitals and the historical justification for their continued tax-exemption. In addition, the ACA contains multiple new imperatives for improving the value, quality, efficiency, and accountability of health care services with systems-based care management applied through integrated

* The author wishes to acknowledge and thank the following individuals for their time and assistance in reviewing and commenting on this article: Shawn Mathis, J.D., L.L.M.; H. Barry Holt, Ph.D., J.D.; Susan L. Watchman, M.P.H., J.D.; and, Professor John D. Blum, M.H.S., J.D.
\end{abstract}


care models. Such models necessarily will require greater alignment of, and cooperation between, stakeholders in multiple delivery systems - nonprofit and for-profit alike.

Collectively, these changes suggest a role for a new organizational paradigm to supplement the traditional binary choice between nonprofit and for-profit corporations as a preferred vehicle for institutional health care delivery. A conceptually-new business entity that can reconcile promotion of the public good with limited profit-seeking accomplished through a legally-enforceable organizational form that acknowledges the legitimate interests of multiple stakeholders while mandating both mission primacy and fiduciary obligation - may well be better-suited to the modern environment and new imperatives of the ACA.

I. INTRODUCTION

II. The ORganizational History OF THE MODERn AMERICAN

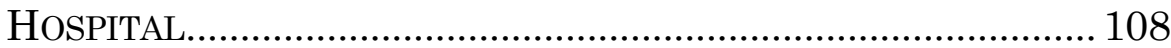

A. The Evolution of the Nonprofit Tradition ...............109

1. Tax-Exemption: From Charity Care to Community

Benefit.....

2. Who Owns the Nonprofit Hospital? ............................114

B. The Medical-Industrial Complex ...........................116

1. The Impact of Third-Party Payment ......................... 120

2. The Resurgence of Investor-Owned, For-Profit

Hospitals ...................................................................... 122

III. The Debate Over Commercialized MEdicine ............. 124

A. Are Nonprofits Better, Worse, or the Same as

For-Profits?

B. Are Nonprofits Abusing Their Tax-Exempt

Status?.

1. Senator Grassley's Crusade........................................ 136

C. The Deontology of Health Care: Is it a Commodity, a

Public Good, or a Right?

1. The Effect of EMTALA and the ACA on Americans'

Right to Health. 140

D. Can Profit-Maximization be Reconciled with the Public Good?.

IV. The Affordable Care ACt: Changing the Focus?.... 145 
A. How Will New ACA Imperatives Affect the

Traditional Organizational Forms?.

1. Industry Consolidation....

a. The demise of physician-owned, specialty

hospitals

2. The Growing Importance of Capital .

3. A Diminishing Need for Charity Care....

a. Additional regulatory burdens on nonprofits....... 155

4. Cornerstone Themes: Quality, Value, Efficiency, and

Accountability.

a. ACOs: Alignment and integration of multiple stakeholders.

B. Is the ACA's Focus Compatible with Commercialized

Medicine?.

V. A NEW Organizational Paradigm .................................... 165

A. The Need for Mission Primacy............................... 166

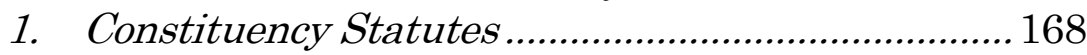

B. Hybrid Legal Structures .......................................169

1. The Flexible Purpose Corporation ............................. 170

2. The Low-Profit Limited Liability Company (L3C).. 171

3. The Benefit Corporation............................................ 172

C. The Fiduciary Medicine Model ............................. 176

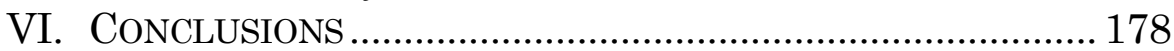

\section{FOREWORD $^{1}$}

[T] he future of healthcare policy in the United States will continue to be characterized by tensions among market-driven, entrepreneurial forces, bureaucratic and administrative regulations, and social/ethical concerns over how best to deliver high-quality and cost-efficient medical services to all citizens. ${ }^{2}$

1 Note: Throughout this article, all internal footnotes in quoted material have been omitted.

2 Joshua E. Perry, An Obituary for Physician-Owned Specialty Hospitals, 23 A.B.A. HEALTH LAW. 24 (2010). 


\section{INTRODUCTION}

wOne need do no more than open a newspaper or turn on

One need do no more than open a newspaper or turn on the television to confirm the truth of the above assertion. Notwithstanding the signing of the Patient Protection and Affordable Care Act (the ACA) on March 23, 2010, and the Supreme Court's resolution of the subsequent constitutional challenge to the ACA in June of $2012,{ }^{3}$ the debate continues seemingly unabated. Reduced to its simplest terms-free of the background din of partisan politics - the central issue revolves around a fundamental and still-unresolved question for the American body politic: what is the nature of health care in the United States? Is it simply a "commodity" like any other product of free-market enterprise, to be consumed to the extent that those of sufficient means are able; is it instead some form of "public good" to be provided only to the extent that public agencies and/or their voluntary, private surrogates choose to do so; or, is it a "right" to which all Americans have some degree of guaranteed entitlement regardless of their ability to pay?

This article will not address the deontological question directly, but will instead focus on the primary mechanism through which most institutional health care in this country has come to be delivered-through what some have referred to as a "binary system" 4 of nonprofit and for-profit hospitals. ${ }^{5}$ Arguably, this system itself both reflects and contributes to the lack of agreement on the fundamental nature of health care in the United States. As such, the structure, function, and limitations of this binary system are worthy of examination to better inform the continuing debate and identify the best means of going forward.

To this end, Section II of this article reviews the

3 Richard Kirsch, The Politics of Obamacare: Health Care, Money, and Ideology, 81 FoRDHAM L. REV. 1737, 1745 (2013).

${ }^{4}$ Katherine R. Lofft, et al., Is a Hybrid Just What the Doctor Ordered? Evaluating the Potential Use of Alternative Company Structures by Healthcare Enterprises, 25 A.B.A HEALTH LAW. 9 (2013).

5 Needless to say, not all health care in this country is delivered by or through hospitals. To focus on organizational forms, however, the discussion will be limited to hospitals as the dominant institutional provider of healthcare services. 
organizational history of the modern American hospital through its charitable, nonprofit origins up to and through the impact of third-party medical insurance and the rise of the "Medical-Industrial Complex." Section III examines the differences between nonprofits and for-profits and a growing concern over nonprofits' alleged abuse of their tax-exempt status. This concern brings into direct focus the commercialization of health care services and the traditional conflict between the organizational goals of profit seeking and pursuit of the public good. Section IV then identifies and describes those provisions of the ACA directed to delivery system reform, specifically addressing the Act's new imperatives for improving value, quality, efficiency, and accountability. Section V follows up by asking whether these imperatives suggest the need for a new organizational paradigm that focuses on "mission primacy" to better serve the needs of multiple stakeholders in integrated delivery systems. Recent efforts trending in this direction are discussed, including "constituency statutes" and various new "hybrid" legal structures. 6 Lastly, a proposed "Fiduciary Medicine Model"7 is discussed, which may well serve as an appropriate conceptual underpinning for such a new paradigm.

Section VI concludes with a specific suggestion for a new organizational form of "Healthcare Benefit Corporation" that could serve to bring pursuit of the public good together with profit-seeking as the explicit and legally-enforceable dual mission of a single business enterprise. ${ }^{8}$ Such proposed new entity may be a desirable supplement to (but not necessarily a replacement for) the traditional nonprofit and for-profit organizational forms-one that is particularly well suited for multi-stakeholder participation in

6 See, e.g., Christen Clarke, California's Flexible Purpose Corporation: A Step Forward, A Step Back, Or No Step At All?, 5 J. BUS. ENTREPRENEURSHIP \& L. 301, 307-309 (2013).

7 See Dayna B. Matthew, Implementing American Health Care Reform: The Fiduciary Imperative, 59 BUFF. L. REV. 715, 744-745 (2011).

8 Ian Kanig, Sustainable Capitalism Through the Benefit Corporation: Enforcing the Procedural Duty of Consideration to Protect Non-Shareholder Interests, 64 HASTINGS L.J. 863, 863 (2013). 
development of Affordable Care Organizations (ACOs) ${ }^{9}$ and otherwise meeting the new imperatives of the ACA.

\section{The ORganizational History OF THE MODERN AMERICAN HOSPITAL}

Before reviewing the history of modern hospital organizations, some background information and a few basic facts are helpful. According to recent data from the American Hospital Association (AHA), in excess of 2,900 of the more than 5,700 U.S. hospitals are private (i.e., nongovernmental), nonprofit facilities. ${ }^{10}$ Moreover, in 2003, $68 \%$ of the 630,000 Medicare-certified beds were operated by nonprofit community hospitals, $16 \%$ by for-profits, and $15 \%$ by nonfederal government facilities. ${ }^{11}$

Organizationally, the principal features distinguishing for-profit from nonprofit hospitals can be summarized as follows. For-profit hospitals: are owned by stockholders, are managed by a stockholder-elected board of directors, raise capital by issuing taxable debt and/or selling equity, and either distribute their net earnings as stockholder dividends or reinvest it to increase stock value. ${ }^{12}$ By contrast, nonprofit hospitals: are not "owned" in the traditional sense, ${ }^{13}$ are managed by either a membershipselected or self-perpetuating (usually unpaid volunteer) board of directors, raise capital through charitable donations and/or the issuance of tax-exempt debt (assuming

9 See infra Section IV.A.4.a.

10 Bobby A. Courtney, Hospital Tax-Exemption and the Community Benefit Standard: Considerations for Future Policymaking, 8 IND. Health L. REV. 365, 367 (2010-2011) (citing Steven T. Miller, Comm'r, Tax Exempt and Gov't Entities, Internal Revenue Serv., U.S. Dep't of the Treasury, Remarks Before the Office of the Attorney General of Texas 2 (Jan. 12, 2009)).

11 Id. (citing Cong. Budget Office, 109th Cong., Pub. No. 2707, Nonprofit Hospitals and the Provision of Community Benefits 3 (2006), available at http://www.cbo.gov/ftpdocs/76xx/doc7695/12-06Nonprofit.pdf.)

12 See Theodore R. Marmor, et al., A New Look at Nonprofits: Health Care Policy in a Competitive Age, 3 YALE J. ON REG. 313, 314, n. 1 (1986).

13 See infra Section II.A.2. 
they have obtained tax-exempt status), and necessarily retain and reinvest all net earnings (termed the "nondistribution constraint"). ${ }^{14}$

\section{A. The Evolution of the Nonprofit Tradition}

It has been said that the modern U.S. nonprofit, taxexempt hospital resulted from a "historical anomaly." 15 That is, hospitals began as donation-supported "alms houses" where volunteers engaged in a purely welfare function - providing refuge for the very sick and dying poor who had no money to have physicians treat them at home. ${ }^{16}$ In 1880, hospitals even prohibited physicians from charging fees to hospitalized patients. ${ }^{17}$ Most of these early hospitals were nonprofit by virtue of their religious affiliation.18 During this time, hospitals and physicians coexisted, largely independently, with hospitals supported by donations and government subsidies and physicians supported by fees from patients with means. ${ }^{19}$

This began to change near the end of the nineteenth century, when medical advances increasingly transformed the hospital into a primary treatment setting for the very ill that depended upon the financial support of fee-paying patients. ${ }^{20}$ Many of the distinctions that previously existed between hospitals and physicians now came to distinguish for-profit from nonprofit hospitals. ${ }^{21}$ That is, for-profit hospitals typically were operated by one or more physicians and served wealthier fee-paying patients; the generally larger nonprofit hospitals continued to rely mostly on philanthropic support, but increasingly came to depend on

\footnotetext{
14 See Marmor, et al., supra note 12, at n. 1.

15 George A. Nation III, Non-Profit Charitable Tax-Exempt Hospitals - Wolves in Sheep's Clothing: To Increase Fairness and Enhance Competition in Health Care All Hospitals Should be For-Profit And Taxable, 42 RuTGERs L.J. 141, 155 (2010).

16 Id.

17 Id. at 156.

18 Marmor, et al., supra note 12, at 321.

19 Id.

$20 \mathrm{Id}$.

$21 \mathrm{Id}$
} 
patient fees to meet the rising costs of their operations. ${ }^{22}$ By 1900, 60\% of all operating hospitals were for-profit, most privately owned by one physician. ${ }^{23}$ By 1922, patient fees accounted for $65.2 \%$ of all hospital revenue, public appropriations for $17.7 \%$, endowments for $3.6 \%$, and donations for $5.7 \% .^{24}$

The period from 1900 to the1950s, however, saw significant growth in the number of nonprofit hospitals as both medical treatment and medical training became more complex, formalized, standardized, and institutionalized. ${ }^{25}$ The resulting financial pressures favored religiously affiliated nonprofits, with their ability to offer donors tax deductions and informal exemption from increasing government oversight. ${ }^{26}$ This in turn brought about a convergence of interests between nonprofit hospitals and physicians: by rejecting the for-profit hospital model, physicians lessened the likelihood of corporate control over their authority, improved their ability to control access to the medical profession, and generally enhanced the financial returns from their individual practices. ${ }^{27}$ As a result, the number of privately owned, for-profit hospitals decreased and the number of tax-exempt, nonprofit hospitals grew. ${ }^{28}$ The 1946 Hospital Survey and Construction Act (the Hill-Burton Act) furthered this trend for the next two decades. ${ }^{29}$

\section{Tax-Exemption: From Charity Care to Community Benefit}

In order to operate as a nonprofit, hospitals today must

\footnotetext{
22 See id.

23 See id. at 322.

24 Nation III, supra note 15, at 156.

25 Marmor, et al., supra note 12 , at 322.

26 Id.

27 Id.

28 See Michael J. DeBoer, Religious Hospitals and the Federal Community Benefit Standard - Counting Religious Purpose as a TaxExemption Factor for Hospitals, 42 SETON HALL L. REv. 1549, 1563 (2012).

29 Id.
} 
first be organized as a nonprofit corporation under state law. Such status is a necessary, but not sufficient, predicate for the corporation to obtain tax exemption. ${ }^{30}$ The corporation must also qualify under current tax-exemption standards. These standards have evolved over many years from the original exemptions granted to earlier religious and charitable institutions. ${ }^{31}$

In the Revenue Act of 1894, Congress first provided income tax exemption for "'corporations, companies, or associations organized and conducted solely for charitable, religious, or educational purposes, including fraternal beneficiary associations." 32 The subsequent Revenue Act of 1909 modified the exemption standard to include "'any corporation or association organized and operated exclusively for religious, charitable, or education purposes, no part of the net income of which inures to the benefit of any private stockholder or individual."'33 In 1917, Congress passed the War Revenue Act, establishing an income tax deduction for donations to tax-exempt organizations by individuals. ${ }^{34}$ This was followed by the Revenue Act of 1918, in which Congress established a similar estate tax deduction. ${ }^{35}$ In the Revenue Act of 1934, lobbying by exempt organizations was limited such that "no substantial part" of their activities "could involve "propaganda' or attempt[s] "to influence legislation." 36 The charitable contribution deduction from income tax was extended to corporations by the Revenue Act of $1936 .{ }^{37}$ The Revenue

30 See Jeremy J. Schirra, A Veil of Tax Exemption?: A Proposal for the Continuation of Federal Tax-Exempt Status for "Nonprofit" Hospitals, 21 HeALTH MATRIX 231, 242 (2011).

31 See DeBoer, supra note 28, at 1559.

32 Id. at 1560 (citing Revenue Act of 1894, ch. 349, § 32, 28 Stat. $509,556(1894))$.

33 Id. at 1566 (quoting Revenue Act of 1909, ch. 6, § 38, 36 Stat. 11, $112(1909))$.

34 Id. at 1561 (citing War Revenue Act of 1917, ch. 63, § 1201(2), 40 Stat. 300 (1917)).

35 Id. (citing Revenue Act of 1918, ch. 18, § 1309, 40 Stat. 1143 (1918)).

36 Id. (citing Revenue Act of 1934, ch. 277, § 23, 48 Stat. 680, 690 (1934)).

37 Id. (citing Revenue Act of 1936, ch. 690, § 101(6), 49 Stat. 1674 
Act of 1943 imposed a requirement that 990 forms $^{38}$ be filed by tax-exempt organizations, although "publicly supported charitable organizations," among a few others, were exempted. ${ }^{39}$ Finally, in the Revenue Act of 1950, Congress subjected tax-exempt organizations to a new "unrelated business income tax (UBIT)," designed to reduce any financial advantage that such organizations might thereby obtain over their tax-paying competitors when conducting "trades and businesses" not "substantially related" to their exempt purpose. ${ }^{40}$ Today, a hospital's tax-exempt status depends on its "designation as 'charitable' under § 501(c)(3)" of the Internal Revenue Code (IRC). ${ }^{41}$

Significantly, Congress has never explicitly defined the

(1936)).

38 The IRS Form 990 is an information form that some nonprofits have to file, disclosing such information as potential conflicts of interest, board composition, financial accountability, etc. See Joanne Fritz, What Nonprofits Need to Know About Form 990, AвоUT.COM, http://perma.cc/9KM4-BPZN.

39 See DeBoer, supra note 28, at 1561 (citing Revenue Act of 1943, ch. $63, \S 117,58$ Stat. 21 (1943)).

40 DeBoer, supra note 28, at 1561-1562 (citing Revenue Act of 1950, ch. 994, 64 Stat. 906 (1950)).

41 Courtney, supra note 10 , at 368 . That section provides: " $\$ 501$. Exemption from tax on corporations, certain trusts, etc. (a) Exemption from taxation. An organization described in subsection (c) or (d) or section 401(a) [IRC Sec. 401(a)] shall be exempt from taxation under subtitle [IRC Sections 1 et seq.] unless such exemption is denied under section 502 or 503... . [(c)](3) Corporations, and any community chest, fund, or foundation, organized and operated exclusively for religious, charitable, scientific, testing for public safety, literary, or educational purposes, or to foster national or international amateur sports competition (but only if no part of its activities involve the provision of athletic facilities or equipment), or for the prevention of cruelty to children or animals, no part of the net earnings of which inures to the benefit of any private shareholder or individual, no substantial part of the activities of which is carrying on propaganda, or otherwise attempting, to influence legislation (except as otherwise provided in subsection (h)), and which does not participate in, or intervene in (including the publishing or distributing of statements), any political campaign on behalf of (or in opposition to) any candidate for public office." Nation III, supra note 15, at 162-163 (citing I.R.C. § 501(a), (c)(3) (2004)) (emphasis added). 
word "charitable." 42 However, in 1956 the Internal Revenue Service (IRS) announced a "substantive rule of charitable purpose" in Revenue Ruling 56-185.43 This ruling, known as the "financial ability standard," provided that tax-exempt hospitals "had to provide charity care to the extent of their ability and "not exclusively for those who are able and expected to pay."'44 Under this standard, hospitals could demonstrate a charitable purpose only by providing medical services free, or below cost, to the poor. ${ }^{45}$ The IRS eliminated the financial ability standard in 1969, ostensibly because of a significant decrease in the number of poor (i.e., uninsured) following the enactment of Medicare and Medicaid in $1965^{46}$ (a situation akin to that expected again under the ACA). This action reportedly was prompted by hospital industry concerns over their feared inability to continue meeting IRS exemption standards following reduced demand for charity care resulting from the increased availability of private and public health insurance. ${ }^{47}$

These, then, were the circumstances that led to development of the modern test for hospital tax-exempt status-the so-called "community benefit standard" promulgated by the IRS in Revenue Ruling 69-545 issued in 1969.48 Subsequently, Revenue Ruling 83-157 in 1983

42 Courtney, supra note 10, at 368.

43 Id.

44 Schirra, supra note 30, at 242.

45 See id. at 243.

46 Id.

47 Courtney, supra note 10, at 369.

48 According to Courtney: "The new Ruling stated that the general law of charity considered promotion of health a charitable purpose; therefore, '[a] nonprofit organization whose purpose and activity are providing hospital care is promoting health and may . . . qualify as organized and operated in furtherance of a charitable purpose.'. . . Revenue Ruling 69-545 further identified five key factors to be considered when determining whether a hospital qualifies for exemption under section 501(c)(3), namely, does the hospital: (1) operate an emergency room open to all persons regardless of ability to pay; (2) provide care to all persons able to pay directly or through insurance; (3) serve a public interest; (4) maintain an open medical staff; and (5) use surplus revenues to improve the quality of care, facilities, medical 
eliminated the requirement in 69-545 of "an emergency room open to all regardless of ability to pay," with the result that hospitals today may qualify as charitable, tax-exempt organizations without providing any free or significantly discounted care to the indigent. ${ }^{49}$

\section{Who Owns the Nonprofit Hospital?}

As previously noted, for-profit hospitals are owned by stockholders, whose individual shares of stock represent pro rata portions of ownership of the total net assets of the organization. Nonprofit hospitals, in contrast, have no such owners by virtue of the nondistribution constraint legally imposed upon their corporate form. Colloquially (and historically), nonprofit assets were often said to be "held in trust for the public good." 50

It is not surprising given nonprofit hospitals' early philanthropic beginnings, and the subsequent requirement of a charitable purpose for tax-exemption, that the governing body of nonprofit hospitals used to be referred to as the "Board of Trustees" (in contradistinction to a forprofit's "Board of Directors"). 51 This was due in part to the fact that those wishing to create new charities would often, at least prior to the nineteenth century, choose to organize as a "charitable trust" rather than a nonprofit corporation. ${ }^{52}$ Accordingly, trust law initially dominated the legal view of nonprofits, including hospitals..$^{53}$

training, education, and research. Determinations were to be made after consideration of 'all of the relevant facts and circumstances in each case,' with the absence of particular factors, or the presence of others, not necessarily being determinative." Courtney, supra note 10, at 369 (citing Rev. Rul. 69-545, 1969-2 C.B. 117) (emphasis added).

49 Nation III, supra note 15 , at 170 (emphasis added).

50 W. Cole Durham \& Robert Smith, Converting a Nonprofit Corporation Into a Business Corporation, Religious Organizations and the Law $\S 7: 29$ (2013).

51 See Evelyn Brody, Charity Governance: What's Trust Law Got To Do With It?, 80 CHI.-KENT L. REV. 641, 642 (2005).

52 See id. at 646.

53 See generally Brody, supra note 51. "Trust law does appropriately dictate specific aspects of the governance of charities, whether trust or corporate. The definition of charity set forth in the Restatement of the 
Trust law, however, has come to be an uncomfortable fit with today's increasingly commercial nonprofit hospitals. ${ }^{54}$ Conceptually, nonprofit corporations lack the "identifiable settler, beneficiaries, and trust purpose" traditionally found in charitable trust law. ${ }^{55}$ Moreover, the investment and distribution activities of charitable and private trusts-the principle focus of trust law-differ substantially from "the active operation of public or quasi-public institutions." 56 From all of this, some conclude that the law governing charitable corporations today "remains an amalgam of trust law, corporate law, and tax law." 57 Others characterize it simply as "neglected and thoroughly muddled." 58 What is clear is that today's commercial nonprofit hospitals (arguably just such "quasi-public institutions") provide a significant percentage of the country's bed inventory, constituting charitable assets worth billions of dollars. ${ }^{59}$

The control of these charitable assets-assertedly "public goods" 60 _became a matter of increasing concern during the 1990s as the revenues of nonprofit hospitals decreased and their capital costs increased, motivating many of them to

Law of Trusts controls across the board, from inheritance disputes to federal tax law. Investment activity by corporate charities is easily analogized to that of trusts. When it comes to enforcing restrictions on gifts - even those made to corporate charities - regulators and courts commonly apply charitable trust doctrines. These include the authority of the state attorney general to enforce the restriction, and the application of the judicial powers of cy pres and deviation when a modification of the restriction is sought. Indeed, some regulators and courts apply trust doctrine to a corporate charity seeking to change its charitable purpose." Id. at 642 .

54 See generally Thomas L. Greaney \& Kathleen M. Boozang, Mission, Margin, and Trust in the Nonprofit Health Care Enterprise, 5 YAlE J. HEALTH POL'Y, L. \& ETHICS 1 (2005).

55 See id. at 54.

56 Brody, supra note 51, at 650 (quoting Edward C. Halbach, Jr., Foreword, Symposium Issue on the Bishop Estate Controversy, 21 U. HAW. L. REV. i, ii (1999)).

57 Thomas Lee Hazen \& Lisa Love Hazen, Punctilios and Nonprofit Corporate Governance - A Comprehensive Look at Nonprofit Directors' Fiduciary Duties, 14 U. PA. J. Bus. L. 347, 351 (2012).

58 Greaney \& Boozang, supra note 54, at 1.

59 See id. at 3.

60 See Hazen and Hazen, supra note 57, at 410. 
sell to or merge with for-profit entities. ${ }^{61}$ This, in turn, caused conflicts in those states where attorneys general were charged with overseeing the preservation or appropriate disposition of such community assets. ${ }^{62}$ In fact, some commentators contend that many of these transactions were fraught with "undervaluation, laxity, and in some cases, management self-dealing" that caused the loss of community assets worth millions of dollars. 63

As a result, by 1998 more than twenty-five states had adopted "nonprofit conversion statutes" specifying requirements for stricter oversight by their attorneys general of such transactions. ${ }^{4}$ The problem is, while these statutes help ensure that charitable corporation assets continue to serve as public goods, the encumbrance of governmental oversight arguably makes the corporation less attractive to potential buyers or merger partners-thus lessening the commercial value of the very community assets such statutes seek to protect. ${ }^{65}$

\section{B. The Medical-Industrial Complex}

At the beginning of the $20^{\text {th }}$ century, the estimated 4,000 general hospitals that had evolved from the $19^{\text {th }}$ century almshouses were transforming into fee charging "business enterprises" that some

61 See generally Richard J. Zall \& Brian J. Kinsella, Going Private: Navigating State Review of Nonprofit Hospital Conversions, AHLA CONNECTIONS (August 2013), archived at: http://perma.cc/7KPA-SJF7.

62 See Greaney \& Boozang, supra note 54, at 4.

63 Id. at 25 (citing John F. Coverdale, Preventing Insider Misappropriation of Not-For-Profit Health Care Provider Assets: A Federal Tax Law Prescription, 73 WASH. L. REV. 1, 3-6 (1998) (describing conversions and attendant abuses); Shelley A. Sackett, Conversion of Not-for-Profit Health Care Providers: A Proposal for Federal Guidelines on Mandated Charitable Foundations, 10 STAN. L. POL'Y REV. 247, 250 (1999) (describing how and why the 1990s saw so many health care conversions); James D. Standish, Hospital Conversion Revenue: A Critical Analysis of Present Law and Future Proposals To Reform the Manner in Which Revenue Generated from Hospital Conversions Is Employed, 15 J. CONTEMP. HEALTH L. \& POL'Y 131 (1998) (explaining the impetus for so many conversions).

64 See Greaney \& Boozang, supra note 54, at 47.

65 See Greaney \& Boozang, supra note 54, at 79 . 
physicians viewed as competitors to their private practices. ${ }^{66}$ Many physicians responded by embracing this new model of hospital in a uniquely American way-as the proverbial "doctors' workshop"67_ where they could obtain "privileges," remain self-employed, yet still bill their hospitalized patients for services that were now supported by the hospitals' staff, equipment, and other resources. ${ }^{68}$ Other physicians who could not or would not obtain hospital staff privileges simply undertook to develop their own hospitals, either individually or with partners, as previously noted. ${ }^{69}$

In 1912, a well-regarded surgeon and author, Dr. James Peter Warbasse, lamented that physicians had become private tradesmen "engaged in a competitive business for profit."70 That same year, an AMA survey of 6,000 physicians "identified three ways in which entrepreneurial, market place medicine was being practiced," with (1) surgeons paying kickbacks to general practitioners for patient referrals; (2) pharmacists and surgical device suppliers paying commissions to physicians who prescribed their products or ordered their supplies; and, (3) hospitals paying "secret commissions" of 15$20 \%$ to physicians for patient referrals to their facilities. ${ }^{71}$ During the 1930 s and 1940s, there were wide reports of physicians who provided no medical services being paid by diagnostic laboratories purely for patient referrals. ${ }^{72}$ In a 1954 article,

Fortune magazine noted the surging
entrepreneurial medicine movement and
labeled it a 'persistent money mania.'
Evidence supporting the claim included
documented incidents of 'clandestine fee
splitting,' the prescribing of 'expensive but

66 Perry, supra note 2, at 24-25.

67 See Joshua E. Perry, A Mortal Wound for Physician-Owned Specialty Hospitals? The Legal and Ethical Prognosis For MarketDriven, Entrepreneurial Medicine in the Wake of 2010 Health Care Insurance Reforms, SOC. SCI. RESEARCH NETWORK (2010) at n.59, archived at http://perma.cc/FBE2-RHYR.

68 See Perry, supra note 2 , at 25.

69 See id.

70 Id. (citing James P. Warbasse, What is the Matter with Medical Profession? 6 LONG IsLAND J. MED. 271-75 (1912) cited in Donald W. Light, Ironies of Success: A New History of the American Health Care “System," 45 J. HEALTH \& Soc. BEHAVIOR 1, 1 (2004)).

71 Id.

72 Id. 
needless shots,' the taking advantage of 'Blue Cross, Blue Shield, and other insurance plans,' and 'the worst abomination of all' - the private ownership by physicians of 'profit-making hospitals. ${ }^{73}$

It wasn't until the 1980s, however-the era of Reagan deregulation and a time when "doctors and patients" instead became "providers and consumers"-that the public began to take note of a "new medical-industrial complex."74 This phrase was originally coined by Arnold Relman, modeled after "President Eisenhower's dreaded military industrial complex of the 1950s." 75 It was frequently used by commentators during the early 1980 s to describe a hospital sector expected to become increasingly dominated by a few national organizations characterized by such corporate practices as service diversification and strategic marketing. ${ }^{76}$ One such commentator was Paul Starr, who in 1982 published The Social Transformation of American Medicine: The Rise of a Sovereign Profession and the Making of a Vast Industry. ${ }^{77}$ In his book, Starr described five different ways by which hospitals would adopt "integrated control" through larger corporate organizations that were removed from the local community:

1. Change from largely public and nonprofit organizations to for-profit;

2. integrate horizontally into multiinstitutional systems, shifting local control to regional and/or national offices;

73 Id. (citing Herrymon Maurer, The MD's Are Off Their Pedestal, ForTUNE, Feb. 1954, at 138).

74 See id. at 26.

75 Marmor, et al., supra note 12, at 317 (citing Arnold Relman, The New Medical-Industrial Complex, 303 NEW EnG. J. MED. 963 (1980)).

76 See Gloria J. Bazzoli, The Corporatization of American Hospitals, 29 J. HEALTH POL. POL’Y \& L. 885, 887 (2004).

77 Paul Starr, The SOCIAL TRANSFormation OF AMERICAN Medicine: The Rise OF A SOVEREIGN PROFEssion AND THE MAKING OF A VAST INDUSTRY (1982). 
3. restructure their organizations to accommodate diversification into conglomerated enterprises operating in various health care markets;

4. integrate vertically to provide a continuum of care; and,

5. consolidate with other providers in order to concentrate ownership and control in regional and national markets. ${ }^{78}$

Starr also suggested that nonprofit hospitals increasingly would come to act like for-profits, adopting "standardized management procedures, standardized accounting, and other uniform practices."79

Starr gets credit for foreseeing many important structural changes that did occur during the 1990s and early 2000s:

Hospitals merged at record rates, with 176 full asset mergers resulting in consolidated ownership between 1990 and 1997. These latter transactions involved nearly four hundred hospitals or about 7.2 percent of the community hospital industry. In addition, about 65 percent of hospitals were involved in some form of multihospital arrangement by 2001-either a health system or a network. In the mid-1990s, hospitals also vertically aligned with physicians through direct purchase of physician practices or contractual relationships, focusing especially on alignment with primary care physicians. Many hospitals and their affiliated physicians prepared to assume the clinical and fiscal responsibility for health care delivery by developing the capacity to manage capitated contracts or by

78 Id. at 429.

79 Id. at $431-32$. 
introducing their own provider-sponsored insurance products. 80

\section{The Impact of Third-Party Payment}

It is not hyperbole to suggest that the sine qua non for the rise of the medical-industrial complex was the development and growth of third-party payment for health care. As Marmor et al. have said: "The introduction of Medicare and Medicaid, together with the growth of private health insurance, sharply increased the flow of funds into the health industry and transformed medicine into a virtual gold-mine for commercial nonprofit as well as for-profit enterprises." 81 It is significant to note that prior to the late

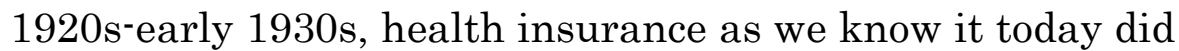
not exist. ${ }^{82}$ Before that time, one could only obtain coverage for loss of income due to illness- so-called "sickness insurance."83 Arguably, modern health insurance started in 1929 when a hospital insurance plan was first set up at Baylor University Hospital by Dr. Justin Ford Kimball. ${ }^{84}$

In the early 1930 s, states passed enabling legislation that, with the assistance of the AHA, led to the formal establishment of Blue Cross plans for hospital insurance and Blue Shield plans for medical insurance (the Blues). 85 By 1940, 10\% of all Americans had health insurance. 86 The continued growth of the Blues reinforced the previously described dominance of nonprofit hospitals during this period, due in part to Blue Cross's favoring nonprofits with

80 Bazzoli, supra note 76 , at 889.

81 Marmor, et al., supra note 12, at 328.

82 See Eleanor D. Kinney, For Profit Enterprise in Health Care: Can It Contribute to Health Reform?, 36 AM. J.L. \& MED. 405, 407 (2010).

83 Id. (citing HARRY Alvin Millis, Sickness and Insurance: A Study of the Sickness Problem and Health Insurance 28-29 (1937); JoHN E. MurRay, ORIGins of AMERICAN HEALTH Insurance: A History OF INDUSTRIAL SICKNESS FUNDS 6 (2007); NAT'L INDUST. CONFERENCE BD., SiCKNESS InsURANCE OR SiCKNESS PREVEnTiOn?, Research Report Number 6 (1918)).

${ }^{84}$ Marmor, et al., supra note 12, at n.43.

85 Id. at 323.

86 Kinney, supra note 82, at 409. 
higher reimbursement rates. ${ }^{87}$ The nonprofits, and later Blue Cross, helped mediate physicians' control over the delivery and financing of medical care. ${ }^{88}$ By 1946, the number of for-profit hospitals had dropped to less than $10 \%$ of total facilities. ${ }^{89}$ Nonetheless, the growing number of feepaying patients brought about by the Blues' expansion of insurance coverage would contribute to an eventual resurgence of for-profit organizations. ${ }^{90}$

In 1957, the percentage of Americans having health insurance had risen to $72 \% .91$ By then, health insurance in the U.S. had largely become a private, employer-based system with two basic benefit plans modeled after the Blues' approach-"one for hospital and extended care facilities, and one for physicians and other providers of outpatient services."92 When Congress adopted the Medicare program in $1965,{ }^{93}$ it utilized essentially this same model. ${ }^{94}$ The initial implementation of Medicare and Medicaid further contributed to a resurgence of for-profit hospitals, as they began increasing their relative market share. ${ }^{95}$

87 See Marmor, et al., supra note 12, at 324.

$88 \mathrm{Id}$.

$89 \mathrm{Id}$.

90 See id. at 324-325.

91 Kinney, supra note 82, at 409.

92 Id.

93 Marmor, et al., supra note 12 , at 325 (citing Social Security Amendments of 1965, Pub. L. No. 89-97 $\S 1801-1875$, 79 Stat. 286 (1965) (current version at 42 U.S.C. $§ \S 1395-1395 z z)$ (1982 \& Supp. V 1985) (Medicare Act providing hospital and medical insurance for the aged, financed by federal payroll taxes); Social Security Amendments of 1965, Pub. L. No. 89-97 §§ 1901-1905, 79 Stat. 343 (1965) (current version at 42 U.S.C. $\S \S 1396-1396 q)$ (1982 \& Supp. V 1985) (Medicaid Act establishing federal matching funds for state medical assistance to the indigent)).

94 See Kinney, supra note 82, at 409.

95 Marmor, et al., supra note 12, at 327 (citing STARR, supra note 77, at 434 ("Expanding private insurance and Medicare gave the financial impetus to proprietary chains.")). 


\section{The Resurgence of Investor-Owned, For-Profit Hospitals}

In the three-five year period before the enactment of Medicare and Medicaid, the market share of for-profit, short-term general hospitals was 5.8\%; in the three-five years after the enactment, that market share rose to $6.2 \% .96$ In addition to the rapid growth of both private and public health insurance, the increase likely was attributable to the for-profit hospitals' more ready access to capital. ${ }^{97}$ By 1980, for-profit, short-term general hospitals accounted for $8.8 \%$ of all services provided, compared to $69.9 \%$ for nonprofits and $21.3 \%$ for public hospitals. 98 Significantly, between 1973 and 1982 the number of hospitals organized into forprofit systems doubled, including many that were formerly nonprofits, public hospitals, or physician-owned. 99 Specifically, by 1982 there were 773 hospitals that were part of 34 for-profit, investor-owned hospital systems. ${ }^{100}$ Adding the additional 282 hospitals that these for-profit chains managed rather than owned at that time gave them control of an estimated $15 \%$ of all hospitals in the U.S. ${ }^{101}$ These hospitals were not randomly distributed, but rather concentrated mainly in the South, Southwest, and West of the country - constituting a third to nearly half of the facilities in Texas, California, Florida, and Tennessee. ${ }^{102}$

By 2011 the AHA was reporting that $20 \%$ of all U.S. community hospitals were investor-owned. ${ }^{103}$ Some current

96 Id. (citing M. Schlesinger, Public, For-Profit and Nonprofit

Enterprises: A Study of Mixed Industries, 76-78, 80 (1984) (unpublished doctoral dissertation, University of Wisconsin at Madison)).

97 See id at 326.

98 Id. at 320 (citing M. Schlesinger, Public, For-Profit and Nonprofit Enterprises: A Study of Mixed Industries, 76-78, 80 (1984) (unpublished doctoral dissertation, University of Wisconsin at Madison)).

$99 \quad$ Id. at 316.

100 Id. at n.7.

101 See Bradford H. Gray, Overview: Origins and Trends, 61 BulL. N.Y. ACAD. MED. 7, 11 (1985).

102 Id.

103 See Thomas P. Weil, Privatization of Hospitals: Meeting Divergent Interests, 38 J. HEALTH CARE Fin. 1 (2011) (citing AMERICAN 
observers predict that-just as with the passage of Medicare/Medicaid-the ACA will once again boost the growth of the for-profit sector ${ }^{104}$ by adding an estimated 32 million more insureds by 2019 , with a corresponding $\$ 40$ billion increase in hospital revenue. ${ }^{105}$

Finally, it should be noted that there was extensive growth during the 1990s and 2000s in the number of forprofit, physician-owned, "specialty" hospitals. ${ }^{106}$ These facilities were developed under a broad and technical reading of the "whole hospital exception" of the Stark Law. ${ }^{107}$ By 2010, the U.S. House of Representatives Budget Committee noted that approximately 265 such facilities were operating, having essentially "taken a "subdivision of a hospital' and made it a freestanding hospital" in circumvention of Stark's prohibition of physician selfreferrals. ${ }^{108}$ This rapid growth brought about extensive governmental and academic scrutiny through the mid2000s, resulting in several reports and studies "revealing varying levels of adverse impacts on general community hospitals, utilization patterns, overall systemic costs, patient safety, and the equitable delivery of care to underserved populations."109 By the end of 2010, calls were

Hospital Association, Fast Facts on United States Hospitals, (2011)).

104 Weil, supra note 103, at 7 (noting that the major investor-owned hospital management corporations in the U.S. are "Community Health Systems, Health Management Associates, Hospital Corporation of America (HCA), Life Point, Tenet, Universal Health Services, and Vanguard.”)

105 See Technical Analysis on Tenet Healthcare and Universal Health: Affordable Care Act, PR NewswiRe, Feb. 8, 2013, archived at http://perma.cc/52ZN-SE5B ("[F]or-profit hospital stocks . . . rallied after the Supreme Court upheld the healthcare reform last year.").

106 See Perry, supra note 2, at 27.

107 Id. (citing 42 C.F.R. § 411.356 (c)(3)(iii) (2010)) ("This exception permitted physicians to maintain an ownership or investment interest in the facility to which they were referring their Medicare patients, as long as the "financial interest was in the entire hospital and not merely in a distinct part or department of the hospital.").

108 Id. (citing H.R. Rep. No. 111-443, at 4 (2010)).

109 Id. (citing generally U.S. GOV'T ACCOUNTABILITY OFFICE, GAO03-683R, SPECIALTY HOSPITALS: INFORMATION ON NATIONAL MARKET Share, Physician Ownership, AND Patients SERVED, 23 (2003)); See also Specialty Hospital Issues, Centers for Medicare \& MedicAid 
strong to increase the regulation of these facilities and "reassess the "whole hospital exception."'110

\section{The Debate Over Commercialized Medicine}

In January 1995, Cardinal Joseph Bernadin, Archbishop of Chicago, said: "I am becoming increasingly concerned that our health care delivery system is rapidly commercializing itself, and in the process is abandoning core values that should always be at the heart of healthcare."111 Such sentiment reflects a continuing debate over the consequences of this country's remarkable progress in medical science and its effect on the way hospitals (and others) have come to deliver health care services. The diametric poles of the debate can be readily seen in the work of two noted health care academics-George A. Nation III, Professor of Law and Business at LeHigh University and Jill R. Horwitz, Assistant Professor of Law at University of Michigan Law School.

Professor Nation contends that hospitals are "first and foremost" engaged in the "business of developing and providing health care services." 112 He argues for increased competition between and among hospitals as the surest way to achieve the highest quality health care at the lowest cost. 113 He further argues that wholesale adoption of a "forprofit taxable business model" in which hospitals are "accountable to investors" is an important predicate to

SERVICES,

http://www.cms.gov/Medicare/Fraud-and-Abuse

/PhysicianSelfReferral/specialty_hospital_issues.html archived at http://perma.cc/K8F4-LZDS (highlighting the 18-month billing moratorium imposed on such hospitals under the Medicare Prescription Drug, Improvement, and Modernization Act of 2003 (MMA) (Pub. L. 108-173)).

110 Perry, supra note 2, at 27-28.

111 Nancy M. Kane, Tax-Exempt Hospitals: What IS Their Charitable Responsibility and How Should It Be Defined and Reported?, 51 ST. LouIS U. L.J. 459, 464 (2007) (quoting David W. Johnson, Managing Director, Citigroup, Presentation at Harvard School of Public Health, Financing the Future: Healthcare Trends and Their Impact on Capital Funding (Mar. 18, 2005)).

112 Nation III, supra note 15, at 180 (emphasis added).

113 Id. at 207. 
increasing competition. ${ }^{114}$ As to nonprofits, he opines:

In the best case, the mission of a modern taxexempt hospital is to keep their tax exemption and then provide the best health care at the lowest cost. In the worst case, a non-profit taxexempt hospital's mission is to keep its tax exemption in order to maximize profits and use their non-profit structure as camouflage to hide both their profit maximizing activities on behalf of doctors and administrators and/or their elitist, secretive (perhaps fraudulent) cross-subsidization of certain types of healthcare and wealth redistribution. ${ }^{115}$

By contrast, Professor Horwitz believes that nonprofits are more than "merely for-profits in disguise[;]" rather, they have their own distinct legal forms and benefits that distinguish their behaviors in meaningful ways from forprofits and governmental facilities:116

Despite widespread beliefs to the contrary, nonprofit hospitals are not required to offer undersupplied services, which tend to be unprofitable, but they choose to do so. ${ }^{117}$

[N]onprofits prioritize some desirable goals, such as providing the right mix of medical services, over profit-maximization. Individual patients, their doctors, and their insurance companies alone cannot contract for the right mix of medical services . . . so they must rely on hospitals to be trustworthy decision makers on their behalf. 118

114 Id. at 181.

115 Id. at 180 .

116 See Jill R. Horwitz, Does Nonprofit Ownership Matter?, 24 YALE J. ON REG. 139, 141 (2007).

117 Id. at 191.

$118 I d$. at 193. 
Nonprofits are different than for-profits. They offer different services, meet different needs, and very likely operate out of motivations of which we (and our liberal tax code) would approve. ${ }^{119}$

\section{A. Are Nonprofits Better, Worse, or the Same as For-Profits?}

A 2006 meta-analysis conducted by the National Bureau of Economic Research of the then-available literature examining the relationship between hospital ownership and financial performance found inconsistent and sometimes contradictory results. ${ }^{120}$ Such inconsistency was attributed, in many instances, to simple differences in the studies' theoretical frameworks, chosen variables, and other model specifications. $^{121}$ Another large body of literature on the relationship between hospital ownership and care quality has also yielded conflicting results, further suggesting that observed inconsistencies may derive from simple differences in analytical methods. ${ }^{122}$ Similarly, a study of mediumsized, nonteaching, general hospitals in Florida found no essential differences attributable to form of ownership along several measures, including "after-tax profit margins, percentages of Medicare and Medicaid patient days, and the dollar value of charity care and [bad] [sic] debt adjustments to revenue." 123 While the authors found "some differences

\footnotetext{
119 Id. at 196.

120 See Courtney, supra note 10, at 377 (citing Karen Eggleston et al., Hospital Ownership and Financial Performance: A Quantitative Research Review 2 (Nat'l Bureau of Econ. Res. Working Paper No. 11662, 2005), archived at http://perma.cc/L7R6-N7T9).

121 Id.

122 See id. at 378 (citing Karen Eggleston et al., Hospital Ownership and Quality of Care: What Explains the Different Results 2 (Nat'l Bureau of Econ. Res. Working Paper No. 12241, 2006), archived at http://perma.cc/W9KD-9EPM.)

123 Frank A. Sloan \& Robert A. Vraciu, Investor-Owned and NotFor-Profit Hospitals: Addressing Some Issues, Health AfFAIRs 1983, at 34, archived at http://perma.cc/V35Y-87DY (noting that Florida has a 33 percent market share of for-profit hospitals).
} 
in the services offered" by nonprofits versus for-profits, they general found "no pattern with regard to "profitable versus nonprofitable services."'124

Notwithstanding these outcomes, several researchers and commentators have reported notable differences between nonprofits and for-profits along a variety of measures. For example, Weil describes several studies showing that: 125

- Nonprofit conversions to for-profit status consistently result in a reduction in the number of employees per occupied bed. ${ }^{126}$

- From 1990 through 2006, for-profits more frequently shut down emergency departments than did nonprofits. ${ }^{127}$

- For-profits more frequently readmit initially discharged Medicare patients. ${ }^{128}$

- Among rural referral centers, for-profits: treat less complicated cases and report "fewer discharges per available bed," maintain "newer physical plant and equipment," and generate higher cash flow margins (19.0\% compared to $8.1 \%$ ) than do nonprofits. ${ }^{129}$

- For-profit rural referral centers achieve a "greater positive cash position" by focusing on controlling the costs of their labor. ${ }^{130}$

$124 \quad I d$.

125 Weil, supra note 103, at 4.

126 Id. (citing Tami L. Mark, Analysis of the Rationale for, and Consequences of, Nonprofit and For-Profit Ownership Conversions, HEALTH SERVICES RESEARCH, Apr. 1999, at 83-101).

127 Id. (citing Renee Y. Hsia, Arthur L. Kellermann \& Yu-Chu Shen, Factors Associated with Closures of Emergency Departments in the United States, 305 JAMA 1978 (2011)).

128 Id.

129 Id. (citing Michael J. McCue \& Preethy Nayar, A Financial Ratio Analysis of For-Profit and Non-Profit Rural Referral Centers, $25 \mathrm{~J}$. RURAL HEALTH 314 (2009)).

130 Id. (citing Michael J. McCue \& Preethy Nayar, A Financial Ratio Analysis of For-Profit and Non-Profit Rural Referral Centers, $25 \mathrm{~J}$. RURAL HEALTH 314 (2009)). 
Similarly, Hellinger cites several articles reporting differences attributable to organizational form:131

- Costs and efficiency results predominantly favor nonprofits, particularly "[a]mong the most sophisticated models of technical efficiency." 132

- After "adjusting for potential confounders," patients in nonprofits have been found to have "uniformly lower probabilities of dying in the hospital" than patients in forprofits. 133

- A study by the U.S. Prospective Payment Assessment Commission determined that nonprofits provide uncompensated care equivalent to $4.5 \%$ of revenues, compared to $4.0 \%$ of revenues provided by for-profits. ${ }^{134}$

- Several other studies also found that forprofits provide less uncompensated care than nonprofits. ${ }^{135}$

- Nonprofits are more likely to provide unprofitable services than for-profits. ${ }^{136}$

131 Fred J. Hellinger, Tax-Exempt Hospitals And Community Benefits: A Review Of State Reporting Requirements, 34 J. HEALTH POL. POL'Y \& L. 37, 45-47 (2009).

132 Id. at 45 (citing Mark Schlesinger \& Bradford H. Gray, How Nonprofits Matter in American Medicine, and What to Do about It. HEALTH AFFAIRS (July 2006), archived at http://perma.cc/D8J3-JL7X).

133 Id. (citing P. J. Devereaux et al., A Systematic Review and Metaanalysis of Studies Comparing Mortality Rates of Private For-Profit and Private Not-for-Profit Hospitals, 166 CANADIAN MED. Ass'N J. 1399, 1399-1406 (2002)).

134 Id. at 46 (citing U.S. Prospective Payment Assessment COMm'n, Medicare and the American Health Care System, Report TO CONGRESS (1996)).

135 Id. (citing Kamal R. Desai et al., Public Hospitals: Privatization and Uncompensated Care, Health Affairs (Mar./Apr. 2000), archived at http://perma.cc/7J46-UM7W).

136 Id. at 47 (citing Mark Schlesinger \& Bradford H. Gray, How Nonprofits Matter in American Medicine, and What to Do about It, HEALTH AFFAIRS (July 2006), archived at http://perma.cc/D8J3-JL7X). 
- A Congressional Budget Office (CBO) study found that nonprofits were more likely to provide the following types of specific unprofitable services: labor and delivery services, emergency room care, high-level trauma care, and intensive care for burns. ${ }^{137}$

Notwithstanding the above findings, Hellinger also identifies a number of articles reporting no, or at most equivocal, evidence of differences-some in the very same articles, but with regard to different measures. ${ }^{138}$

The apparent willingness of nonprofits to provide unprofitable services when and where for-profits don't serves as the primary basis for Horwitz to assert that nonprofits are motivated more often to act in the public interest. ${ }^{139}$ She goes on to suggest that nonprofits accordingly are more likely to consider quality over profitthereby "providing the mix of services that patients would demand if they could." 140 She sees this provision of services "with variable profits" as strongly supporting an "objectives theory" of hospital behavior. ${ }^{141}$ That is to say, hospitals behave differently because they have different objectives. It

137 Id. (citing U.S. Congressional Budget Office, NonProfit Hospitals AND THE PRovision of Community Benefits (2006)).

138 Id. at 45-47 (citing Frank A. Sloan, Not-for-Profit Ownership and Hospital Behavior, in HandBoOK of Health Economics, (A. J. Culyer \& J. P. Newhouse eds., 2000); The Tax-Exempt Hospital Sector: Hearing before the H. Comm. on Ways and Means, 109th Cong. 142-155 (2005) (joint statement of Mark Schlesinger \& Bradford H. Gray, Urban Institute); citing Mark Schlesinger \& Bradford H. Gray, How Nonprofits Matter in American Medicine, and What to Do about It, HEALTH AFFAIRS (July 2006), archived at http://perma.cc/D8J3-JL7X; citing Emmett B. Keeler et al., Hospital Characteristics and Quality of Care, 268 JAMA 1709 (1992); Jeannette Rogowski et al., Hospital Competition, Managed Care, and Mortality after Hospitalization for Medical Conditions, 42 Health Servs. Research 682 (2007); U.S. CONGREssional Budget OfFice (CBO), NONPROFit Hospitals AND THE Provision OF COMMUNITY BENEFITS (2006), archived at http://perma.cc/GK5X-D5GA).

139 See Horwitz, supra note 116, at 139.

140 See id. at 193-194.

141 See id. at 175. 
takes no great theoretical reach to conclude that forprofits-motivated primarily by profit-maximization-are more likely to "avoid unprofitable patients" than nonprofits. ${ }^{142}$

This perception, that nonprofit hospitals are motivated more often to act in the public interest, has resulted in what many commentators refer to as the "halo effect"143-the propensity of people to see nonprofits as more trustworthy than for-profits. A less metaphorical explanation can be found in "Information Asymmetries Theory." According to this theory, "information asymmetries" exist "when one party to a transaction possesses information that another party does not," and/or "when the purchaser of a good or service cannot easily ascertain the quality of the good or service."144 It is clear that in the hospital-patient relationship, both conditions pertain-hence Horwitz's emphasis on the relevance of patient trust. Such trust, however, has come under ever more strain as both forms of health care organization display increasingly adverse effects of the industry's growing commercialization. ${ }^{145}$

\section{B. Are Nonprofits Abusing Their Tax-Exempt Status?}

According to former IRS Commissioner Mark W. Everson:

What we have seen since 1969 has been a convergence of practices between the for-profit and nonprofit hospital sectors, rendering it

142 See id. at 157.

143 See Peter Molk, Reforming Nonprofit Exemption Requirements, 17 Fordham J. CorP. \& Fin. L. 475, 532 (2012) (citing Burton A. Weisbrod, ThE NONPROFIT ECONOMY VII (1988) (noting that some people think certain nonprofits are "safer" than for-profits); see also Hearing on Gov't Waste and Tax Abuses by Gov't and Nonprofit Entities Before the Subcomm. on Procurement, Taxation and Tourism of the H. Comm. on Small Business, 103d Cong. 1 (1994) (statement of Rep. James D. Santini, Chairman, Business Coalition for Fair Competition), reprinted in 94 TAX Notes TODAY, 117-25 (June 17, 1994) (noting the "halo advantage" nonprofits possess when dealing with the public)).

144 Id. at $482-483$.

145 See Marmor, et al., supra note 12, at 343. 
increasingly difficult to differentiate for-profit from non-profit health care providers. In our review of tax-exempt hospitals, some of the issues we are finding include complex joint ventures with profit-making companies, excessive executive compensation, operating for the benefit of private interest rather than the public good, unrelated business income and employment taxes. ${ }^{146}$

These commercialization effects are coming under increasing scrutiny and, in some cases, direct attack. Numerous studies, reports, and articles have come out over the last ten years documenting various "bad acts" by taxexempt, nonprofit hospitals. ${ }^{147}$ In most instances, these acts are not illegal, but are rather in the nature of behavior "that falls below broadly held social expectations of charitable hospitals and health systems."148 Moreover, "legal" does not mean "harmless"-it was reported in 2009 that most personal bankruptcies in the United States are caused by medical bills that cannot be paid. ${ }^{149}$

Examples of bad behavior on the part of nonprofit hospitals include: failing to disclose the availability of Medicaid and/or institutional free care or charity care programs; 150 the use of predatory and aggressive collection tactics; 151 charging indigent and uninsured patients more than what the hospital routinely accepts as payment in full

146 Hellinger, supra note 131, at 38 (citing, The Tax-Exempt Hospital Sector: Hearing Before the Comm. on Ways and Means U.S. House of Representatives, 109th Cong., Serial No. 109-17, (May 26, 2005) (Statement of Mark Everson, Comm'r of the Internal Revenue Serv.).

147 See Amanda W. Thai, Is Senator Grassley Our Savior?: The Crusade Against "Charitable" Hospitals Attacking Patients for Unpaid Bills, 96 IOWA L. REV. 761, 771 (2011).

148 Kane, supra note 111, at 470.

149 See Thai, supra note 147, at 763 (citing Catherine Arnst, Study Links Medical Costs and Personal Bankruptcy, Bus. WK., (June 4, 2009), archived at http://perma.cc/5XBT-F'VHX.

150 See id. at 770.

151 Id. at $770-771$. 
from insurance plans; 152 and, arguably worst of all, bringing suit against former patients for bad debt. ${ }^{153}$ Consider two particularly egregious examples:

- "In 2002, Yale-New Haven Hospital, the largest charitable healthcare provider in New Haven, Connecticut, filed 426 lawsuits against patients." 154

- "Up until very recently, forty percent of the total judgments in Roanoke City General District Court-roughly 33,000 judgments since 2003-resulted from claims by Southwest-Virginian 501(c)(3) Carilion Clinic. In one year, Carilion sued 9888 patients, garnished the wages of 5478 people, and placed liens on 3920 homes." 155

By the mid-2000s approximately seventy federal class action suits alleging excessive charges and overly aggressive collection activities had been brought against individual nonprofits and hospital systems, as well as the American Hospital Association. ${ }^{156}$ While these federal suits largely failed, ${ }^{157}$ many plaintiffs were more successful in state courts proceeding under broad consumer-fraud statutes. ${ }^{158}$ As a consequence, plaintiffs' lawyers obtained settlements from major nonprofit hospital systems in several states,

152 See id. at 769-770.

153 See id. at 771.

154 Id. (citing CONN. CTR. FOR A NeW ECON., Uncharitable Care: Yale-New Haven Hospital's Charity Care and Collections Practices 19 (2003), archived at http://perma.cc/U92U-43VP.).

155 Id. (citing Laurence Hammack, Carilion Cases Dominate General District Docket, RoAnoke Times, (Sept. 14, 2008), archived at http://perma.cc/JTP9-JUGB).

156 Horwitz, supra note 116, at 155.

157 Ostensibly because of weak tax-exemption arguments predicated on the idea that "the uninsured were third-party beneficiaries of implied contracts between the hospitals and the federal and state government[s] ..." Id.

158 See Joseph Goldstein, Exerting Their Patients, A.B.A. J., May 2009 . 
including: California, Missouri, and Illinois.159 Further, these successes began motivating state legislatures to propose bills governing hospitals' billing practices and charity care policies. ${ }^{160}$

Beyond financial harm to individuals, other practices have also raised questions about the appropriateness of nonprofit hospitals' continued tax-exempt status. One such concern is nonprofit CEO salaries: "A recent study of fourteen tax-exempt hospitals in Florida's Tampa Bay area revealed that the average compensation for chief executives at those hospitals was about $\$ 876,000$-drastically higher than the national average of $\$ 490,000 . " 161$ Many believe that such salaries, if justifiable at all, should depend more on hospital executives' demonstrated ability to meet their communities' needs rather than their organizations' success at profit making. 162

Another concern relates to the accuracy of nonprofit hospitals' financial reporting of charity care-mandated in response to regulatory pressures against excessive profit. ${ }^{163}$ For example, after surveying 544 hospitals the IRS noted that some facilities apparently overstate their level of uncompensated care by reporting their services at "retail price"164 rather than "cost."165

A third concern is the perception that many nonprofit

159 Id.

160 See Kane, supra note 111 , at 461.

161 Thai, supra note 147, at 782 (citing Kris Hundley, Economic Downturn? Not for These Tampa Bay Nonprofit Hospital Chiefs, ST. PETERSBURG TIMES, (Jan. 31, 2010), archived at http://perma.cc/2EHGYV8M).

162 See id.

163 See Peter Cram, et al., Uncompensated Care Provided by ForProfit, Not-For-Profit, and Government $O_{\text {wned Hospitals, BMC HEALTH }}$ SERVICES RESEARCH 2010, 10:90 (2010), available at http://www.biomedcentral.com/1472-6963/10/90.

164 Most hospitals establish a price list-the so-called "Chargemaster"-which essentially represents "the hospital's initial bargaining position from which insurers negotiate down." These are also the prices that some hospitals have charged "indigent and uninsured patients," as previously noted. See Goldstein, supra note 158 , at 19 .

165 See Goldstein, supra note 158, at 20. 
hospitals are taking advantage of their comparatively lower cost of capital through the tax-exempt debt markets "at the expense of community benefit." 166 That is, in a practice called "tax arbitrage," some nonprofits have financed their capital projects through tax-exempt bond debt instead of using their own available investment assets. ${ }^{167}$ According to Kane:

One study found that over half the tax-exempt debt held by hospitals in 1996 could have been eliminated if hospitals had used their 'endowment assets' before borrowing. The same study also found that both endowment assets and tax-exempt bonds are concentrated in a minority of hospitals, indicating that tax subsidies are benefiting cash-rich hospitals while not helping those cash-poor hospitals most in need of outside financing. ${ }^{168}$

Finally, the biggest concern is undoubtedly the amount of money that government at all levels is losing in foregone tax revenue. In 2002, the value to U.S. nonprofit hospitals of major federal, state, and local tax exemptions was estimated to be approximately $\$ 12.6$ billion. ${ }^{169}$ This included: " $\$ 2.5$ billion in federal corporate income taxexemptions, $\$ 1.8$ billion in federal tax-exempt-bond financing, $\$ 1.8$ billion in charitable contributions (federal),

166 See Paula H. Song, Jeffrey S. McCullough \& Kristin L. Reiter, The Role of Non-Operating Income in Community Benefit Provision By Not-For-Profit Hospitals, 39 No. 3 J. Health CARE Fin. 59, 60 (2013) (citing Congressional BudGet OfFice, NonProfit Hospitals AND TAX ARBITRAGE (2006), archived at http://perma.cc/UFC7-HXPF).

167 E.g., "unrestricted marketable securities that were earned through unrestricted gifts, investment income, retained earnings, and funded depreciation." Kane, supra note 111, at 466.

168 Id. (citing William M. Gentry, Debt, Investment, and Endowment Accumulation: The Case of Not-for-Profit Hospitals, $21 \mathrm{~J}$. OF HEALTH ECON. 845, 871 (2002)).

169 Courtney, supra note 10, at 376 (citing Cong. BUDGET OfFICE, 109Th Cong., Pub. No. 2707, NonProfit Hospitals AND the Provision of COMMUNiTY Benefits 5 (2006), archived at http://perma.cc/34CEVRXT). 
$\$ 500$ million in state corporate income tax exemptions, $\$ 2.8$ billion in state and local sales tax exemptions, and \$3.1 billion in local property tax exemptions."170 Hellinger contends that (1) even though there is some evidence that nonprofits provide more unprofitable services and more uncompensated care than for-profits, and (2) even though $80 \%$ of nonprofits' uncompensated care exceeds the value of their tax exemption, these efforts are insufficient to justify such facilities' continued tax-exempt status. ${ }^{171}$

As one example reflecting this growing opinion, the Supreme Court of Illinois ruled in March 2010 that Provena Covenant Medical Center in Urbana had failed to provide charity care sufficient to justify its exemption from state property taxes. ${ }^{172}$ Another example is the current fight between the mayor of Pittsburgh and the University of Pittsburgh Medical Center (UPMC). ${ }^{173}$ Pointing to UPMC's 2012 CEO compensation exceeding $\$ 6$ million, and the more than $\$ 1$ million paid to each of more than twenty other UPMC executives that same year, the city has sued the taxexempt nonprofit to force it to pay property and payroll taxes-charging that "the health care system operates more like a for-profit corporation than a charitable organization dedicated to the local community."174 As a result of a growing number of such examples, several states have passed legislation either requiring or encouraging additional "community benefit reporting" by hospitals. ${ }^{175}$

170 Id.

171 See Hellinger, supra note 131, at 55-56.

172 Kinney, supra note 82, at 427 (citing Provena Covenant Med. Ctr. v. Dep't. of Revenue, 2010 WL 966858 (Ill. Mar. 18, 2010), aff'g, 384 Ill.App.3d 734, 894 N.E.2d 452 (2009); see also Utah County v. Intermountain Health Care, Inc., 709 P.2d 265, 269 (Utah 1985)).

173 See Kate Picket, A Tax Fight in Pittsburgh and the Future of Non-Profit Hospitals Nationwide, TIME SWAMPLAND, June 10, 2013, archived at http://perma.cc/TK5X-ABS2.

174 Id.

175 See Courtney, supra note 10, at 372 (citing Cal. Health \& Safety Code $\S \S 127350,127355$ (LexisNexis 2010), Idaho Code Ann. $\S$ 63-602D (2010); 210 Ill. Comp. Stat. Ann. 76/15, 76/20 (LexisNexis 2010); Ind. Stat. Ann. $\S \S$ 16-21-9-4-16-21-0-7 (LexisNexis 2010); Md. Code Ann., Health-Gen. § 19-303 (LexisNexis 2010); N.H. Rev. Stat. Ann. §§ 7:32-e7:32-g (LexisNexis 2010); N.Y. Pub. Health Law § 2803-1 (Consul. 


\section{Senator Grassley's Crusade}

In 2005, Senator Charles E. Grassley (Iowa), Chairman of the Senate Finance Committee, and Representative Bill Thomas (California), Chairman of the House Ways and Means Committee, began to question whether the value nonprofits receive from their tax-exemption exceeds the benefit communities receive in return. ${ }^{176}$ Specifically, Grassley questioned the appropriateness of "hospital executive compensation levels, joint ventures with commercial organizations, and hospital for-profit subsidiaries."177 In May of that year, Senator Grassley sent letters to ten large nonprofit hospitals, asking that they "account for their charitable activities."178

In June 2006, the Senator asked the IRS to report on its efforts to ensure that nonprofits were complying with federal tax rules. ${ }^{179}$ The IRS subsequently asked more than 550 tax-exempt, nonprofit hospitals to complete a compliance questionnaire. ${ }^{180}$ In July of that year, Grassley "questioned Treasury Secretary Nominee Eric Solomon about his commitment to regulating tax-exempt hospitals, in particular mandating charity care and community benefit requirements." 181

The Senate Finance Committee considered a number of health care reform policy options distributed by Senators

2010)).

176 Kane, supra note 111, at 459-460.

177 Id. at 460 (citing Letter from Charles E. Grassley, Chairman, Committee on Finance, U.S. Senate, to Richard J. Davidson, President, American Hospital Association (Mar. 8, 2006)).

178 Courtney, supra note 10, at 375 (citing Press Release, Grassley Asks Non-profit Hospitals to Account for Activities Related to Their Tax-exempt Status (May 27, 2005), archived at http://perma.cc/JY5AT6U7).

179 Horwitz, supra note 116, at 154 (citing Sen. Grassley Asks IRS to Step Up Oversight of Health Care Nonprofits, 14 Health CARE POL'Y REP. (BNA) No. 23, at 759 (June 5, 2006)).

180 Id. at 154-155 (citing Robert Pear, I.R.S. Checking Compliance by Tax-Exempt Hospitals, N.Y. TiMES, June 19, 2006, at A15).

181 Id. at 155 (citing Grassley Seeks Assurances from Solomon on Charity Hospitals' Tax-Exempt Status, DaILY TAX ReP. (BNA) No. 136, at G1 (July 17, 2006)). 
Grassley and Max Baucus in May 2009.182 These options were released as proposed legislation entitled "America's Healthy Future Act of 2009" on September 22, 2009 and included "requirements for community needs assessments, financial assistance policies, charge limitations, collection policies, as well as reporting and disclosure."183 Even though Congress never passed this legislation, most of Senator Grassley's proposals were later incorporated into the ACA, as discussed in Section $\operatorname{IV(A)(3)(a)~infra.~}{ }^{184}$

\section{The Deontology of Health Care: Is it a Commodity, a Public Good, or a Right?}

If health care is a commodity like all others, then there is no basis for characterizing much of the above-described hospital conduct as bad acts. Alternatively, if health care is a public good-in either the generic or economic sense of the word-then the public is justified in expecting better behavior from nonprofits as the equitable quid pro quo for tax-exemption. If, however, health care is a right to which all Americans are entitled regardless of their ability to pay, then one can fairly ask whether such services can ever be reliably and ethically provided by any institutional provider that is primarily motivated by profit, regardless of that provider's nominal organizational form.

Reflective of the world view that health care is just another commodity are the reported comments of John McDaniel, Executive Director of American Medical International's St. Jude Hospital in New Orleans, justifying his organization's tough collection practices: "Grocery stores don't have to provide food to the indigent."185

182 Courtney, supra note 10, at 375 (citing S. Fin. Comm., 111th Cong., Financing Comprehensive Health Care Reform: Proposed Health System Savings and Revenue Options (Comm. Print 2009)).

183 Id. at 376 (citing America's Healthy Future Act of 2009, S.1796, 111th Cong. (2009), available at http://frwebgate.access.gpo.gov/cgibin/getdoc.cgi?dbname=111_cong_bills\&docid=f:s1796pcs.txt.pdf).

184 Thai, supra note 147, at 763 (citing Patient Protection and Affordable Care Act $\S \S 9001-9023$ (adopting S. $1796 \S \S 6000-6023)$ ).

185 See Marmor, et al., supra note 12, at 344-345 (citing Grady, The Cruel Price of Cutting Medical Expenses, Discover, May, 1986, at 25, 
Few scholars of health care today would subscribe to Mr. McDaniel's view. As Marmor, et al. put it:

This casual remark is terribly revealing in its acceptance of this business-like aspect of health care. This acceptance reflects a guiltless dismissal of centuries of concern that the care of the sick imposes special obligations on both the givers of care and the community as a whole. Of equal concern is the behavior of the nonprofit institutions that carefully nurture reputations for community service while, at the same time, transferring costly cases to the local county hospitals. The relative triumph of commercialism and the long decline of professional authority mark a major shift in the character of American medicine. ${ }^{186}$

The idea of health care as a public good is often used in two different senses: first, is in the generic sense of "public benefit"-the provision of which is deemed to be the justification for granting nonprofit providers taxexemption; ${ }^{187}$ second, is in the economic sense of goods that are both "nonrival and nonexcludable."188 In this context, such terms are taken to mean goods that can be consumed simultaneously by more than one person at the same level (i.e., nonrival), and that cannot be readily excluded from anyone's consumption (i.e., nonexcludable). 189 Thus, "once the good is provided, all individuals can consume it regardless of their contribution to the good"-giving rise to the so-called "free-rider problem." 190 These characteristics are said to result "in an inefficiently low observable demand for the good (in terms of who is willing to pay for it), and

40).

$186 \quad I d$. at 345.

187 See Hazen \& Hazen, supra note 57, at 365-366.

188 See Horwitz, supra note 116, at 194.

189 See Molk, supra note 143, at 480.

190 See id. 
hence a socially suboptimal under-provision of the good."191 Under a "Public Goods Theory," then, to the extent that government does not provide sufficient quantities of the good, nonprofits arise to do so-again, the arguable justification for their tax-exemption. ${ }^{192}$ The point can be illustrated by trauma centers: because they are expensive to develop and typically lose a lot of money, they are rarely established by for-profit hospital organizations. ${ }^{193}$

Last is the politically charged idea of health care as a right or entitlement. In view of the complexity of the issue, only a limited number of observations will be offered here. During the 1960s, the United Nations (UN) developed the International Covenant on Economic, Social and Cultural Rights (ICESCR)_an international covenant under the UN Universal Declaration of Human Rights (UDHR), positing in its Article 12 a "human right to health" that includes "the enjoyment of the highest attainable standard of physical and mental health." 194 Included in the "core content" of the right to health, as outlined in General Comment 14 to the ICESCR, are "essential primary health care, minimum essential and nutritious food, sanitation, safe and potable water, and essential drugs."195 Similarly, the constitution of the World Health Organization (WHO) "states a right to the 'highest attainable standard of health' and defines health broadly as 'a state of complete physical, mental and social well-being and not merely the absence of disease or infirmity."196 In addition, several other

191 Id. at 481 (citing JAMES M. BUCHANAN, COLlECTED Works OF James M. Buchanan: The Demand AND Supply of Public Goods 12-15 (1999)).

192 See id. at 481-482.

193 See Horwitz, supra note 116, at 194.

194 Eleanor D. Kinney, Realizing the International Human Right to Health: The Challenge of For Profit Health Care, 113 W. VA. L. REV. 49, 50 (2010) (citing International Covenant on Economic, Social and Cultural Rights, G.A. Res. 2200 (XXI) A, U.N. Doc. A/6316 at 51 (Dec. $16,1966)$ ).

195 Id. at 51 (citing The Right to Health, World HEALTH ORG (Nov. 2013), archived at http://perma.cc/F2ZX-EGPK).

196 Id. at 53 (citing Constitution of the World Health Organization, opened for signature, July 22, 1946, 62 Stat. 6279, 14 U.N.T.S. 185 (entered into force Apr. 7, 1948)). 
international authorities and regional treaties also address a "human right to health" and prohibit conduct by governments detrimental thereto. ${ }^{197}$

\section{The Effect of EMTALA and the ACA on Americans' Right to Health}

It is obvious that the body politic in the United States continues to debate whether Americans have, need, or want a "right to health" as recognized in many other parts of the world. Nonetheless, it is instructive to consider the degree to which the Emergency Medical Treatment and Active Labor Act (EMTALA) and the ACA together are moving the country in that direction.

In 1986, Congress enacted EMTALA in response to a growing problem with "patient dumping." 198 Prior to that time, there was no uniform statutory or common law requirement for hospitals to treat anyone. ${ }^{199}$ As a result, it was not unusual for hospitals to "dump" patients who presented at the emergency room with no ability to pay by simply refusing to treat them or by transferring them elsewhere. ${ }^{200}$ This problem appeared to worsen following implementation of the Medicare Prospective Payment System in 1983.201 In response, Congress sought to take steps to protect "traditional community responsibilities" and "historic standards."202 EMTALA requires those hospitals that have an emergency room and also participate in Medicare ${ }^{203}$ to provide for "appropriate medical screening" of all persons (regardless of their payment status) who present for examination or treatment of a medical condition,

197 Id. at 52.

198 Alexa E. Welzien, Balancing EMTALA's Duty to Stabilize Hospital Inpatients and CMS's Regulations in the Midst of a Struggling Hospital Industry, 23 No. 6 HEALTH LAW. 21, 21 (2011).

199 See id. at 23.

200 Id. at 21.

201 Id. at 23.

202 See id. (citing H.R. REP. NO. 99-241, at 27 (1985), reprinted in 1986 U.S.C.C.A.N. 579, 605.).

203 Id. at 21. Medicare participation, as a practical matter, includes virtually all hospitals. 
in order to "determine whether a medical emergency" exists. ${ }^{204}$ If an emergency medical condition is found, the hospital must provide such further examination and treatment as necessary to stabilize the condition prior to discharging or transferring the patient to an appropriate, alternate facility. ${ }^{205}$

That is not to say, however, that this treatment is provided for free or that the patient does not remain financially responsible for the costs of the services they receive. Thus, while EMTALA ensures that patients having medical emergencies will not "die on the doorsteps of the hospital," it does not shield them from some of the harsh collection efforts previously described or prevent them from being forced into bankruptcy over unpaid medical bills.

This is where the ACA now comes into play in two ways. First, the ACA's "individual mandate"-the requirement that all "applicable individuals" maintain "minimum essential" health insurance coverage ${ }^{206}$ —is expected to add 32 million more insureds by 2019. ${ }^{207}$ Second, the ACA's new "community benefit requirements" 208 now prohibit nonprofit hospitals from charging uninsured emergency patients more than they charge insured patients, and engaging in "extraordinary billing and collection actions without first making 'reasonable efforts to determine whether the individual is eligible for assistance under the [hospital's] financial assistance policy." ${ }^{209}$ The combined effect of EMTALA and these ACA provisions thus goes a long way toward ensuring that all Americans can and will receive at least emergency health care services when needed. However, a "human right to health" for everyone that includes "the enjoyment of the highest attainable standard of physical and mental health" remains another matter.

204 See id. at 21 (citing 42 U.S.C. § 1395dd(a) (2014)).

205 See id, (citing 42 U.S.C. $§ 1395 d d(b)$ (2014)).

206 See 42 U.S.C. $\S 18091$ (2014).

207 See supra Section II(B)(2).

208 See infra detailed discussion in Section IV(A)(3)(a).

209 See Welzien, supra note 198, at 30 (citing 26 U.S.C. $§ 501(\mathrm{r})(3)$ (6) (2014). 


\section{Can Profit-Maximization be Reconciled with the Public Good?}

"No man can serve two masters: for either he will hate the one, and love the other; or else he will hold to the one, and despise the other. Ye cannot serve God and mammon." 210

Because they do not receive the financial advantages of tax-exemption, for-profit hospitals do not have a reciprocal obligation to provide community benefit. Moreover, nonprofits that joint venture with for-profit entities-even if ostensibly done to expand services, increase uncompensated care, or otherwise increase community benefit-actually risk losing their tax-exempt status. ${ }^{211}$ In fact, prior to the early 1980s the IRS viewed all such joint ventures as per se improper. ${ }^{212}$ In 1983, the IRS modified its position by adopting a new two-pronged test: (1) "the "charitable purpose' test," examining whether or not the venture furthers the nonprofit's tax-exempt purpose; and, (2) "the "private benefit' test," evaluating whether the venture operates exclusively for the nonprofit's charitable purpose and/or "results in more than incidental benefit to the forprofit partner." 213 It is obvious, however, that the IRS still perceives an inherent conflict between the pursuit of public good and profit seeking.

Of course, for-profits can and do provide community benefit. Indeed, as previously noted, some commentators maintain that "investor-owned system hospitals and not-for profit hospitals are virtually identical in terms of . . the dollar value of charity care." 214 Be this the case or not, it is clear that many for-profits will engage in community benefit

210 Justin Blount \& Kwabena Offei-Danso, The Benefit Corporation: A Questionable Solution to a Non-Existent Problem, 44 ST. MARY's L. J. 617, 618 (2013) (citing Matthew 6:24 (King James)).

211 See Gail Rebecca Floyd, Nonprofit Joint Ventures and Community Benefit: A New Approach, 58 Fed. Law. June 2011, at 23, 25 (2011).

212 See id.

213 Id. (citing I.R.S., Gen. Couns. Mem. 39,005 (June 28, 1983)).

214 Sloan \& Vraciu, supra note 123 at 25. 
activities, if for no reason other than to promote their informed self-interest-that is, to appear as good corporate citizens and remain competitive in nonprofit-dominated markets. It is equally clear that nonprofits cannot operate in today's increasingly commercialized health care environment without a steady eye on the financial bottom line. As with many things, it all seems to be a question of degree and thus subject to continuing controversy.

\section{The Legal Duties of Hospital Governing Bodies}

The controversy is perpetuated in part by the law of corporate governance as it has evolved in this country. Kanig describes it well:

During the Great Depression, a famous exchange between Adolf Augustus Berle and Edwin Merrick Dodd on the pages of the Harvard Law Review phrased the question thusly: Are corporations solely responsible to private ownership interests, or do they also possess obligations to benefit the general public welfare? Lines were drawn in the intellectual sand between Berle's 'shareholder primacy' theory and Dodd's 'stakeholder theory' of corporate governance-the former embracing corporations as private property, the latter as an integral component of any comprehensive system of social welfare. The future of corporate law and the culture of American business were at stake. . . [S]hareholder primacy theory triumphed in the courts, and the 'shareholder wealth maximization norm,' which made the promotion of shareholder returns the exclusive mandate of corporate [decision-making] [sic], was unshakably ingrained into the corporate ethos. The effects of this normative choice were enormous. ${ }^{215}$

215 Kanig, supra note 8, at 870 (emphasis added). 
Kanig goes on to note that "the victory of shareholder wealth maximization had already been presaged by the seminal decision of Dodge v. Ford Motor Company" in 1919, wherein the Michigan Supreme Court held:

\begin{abstract}
A business corporation is organized and carried on primarily for the profit of the stockholders. The powers of the directors are to be employed for that end. The discretion of directors is to be exercised in the choice of means to attain that end, and does not extend to a change in the end itself, to the reduction of profits, or to the nondistribution of profits among stockholders in order to devote them to other purposes. ${ }^{216}$
\end{abstract}

Under the law, as it still exists today, few would question the potential liability of a for-profit director who failed to act in the shareholders' best interest by not pursing profit on their behalf, or one who otherwise subordinated shareholders' interests to some other purpose, be it public or private.

The primary legal duty of a nonprofit director stands in stark contrast. At the outset and as previously noted, nonprofits have no shareholders whose wealth must be maximized. Rather, any profits earned by the charitable, nonprofit corporation must be used only in ways that further the charitable interest of the organization. ${ }^{217}$ This is the charitable, nonprofit corporation's raison d'être and the corresponding mandate of such corporation's directors.

It should be noted that all corporate directors-for-profit and nonprofit alike-are subject to certain legally recognized fiduciary duties. These generally include a "duty of care," a "duty of loyalty," a "duty of good faith," and a "duty of obedience." 218 Of these, the duty of obedience is

216 Id. at 877 (quoting Dodge v. Ford Motor Co., 170 N.W. 668, 684 (Mich. 1919) (emphasis added)).

217 Id. at 884.

218 See Hazen \& Hazen, supra note 57, at 355. 
particularly relevant to nonprofit directors since it specifically involves fealty to the organization's mission. ${ }^{219}$ From this, some have argued that charitable, nonprofit directors should be held to even "higher standards of care and loyalty" because their organizations "comprise a public good." 220

Moreover, the role of a nonprofit director arguably is more challenging. Unlike the straightforward goal of profitmaximization in a for-profit, a nonprofit's goals are generally more complex, multi-faceted, and frequently ill defined. ${ }^{221}$ The role of nonprofit directors is said to be more "nuanced," requiring the reconciliation of both business objectives and mission-what some have termed a "balance of mission and margin."222 That many believe this balance often has been missed is shown by the actions of Senator Grassley and the new community benefit requirements recently promulgated under the ACA. ${ }^{223}$

\section{The AfFordable Care ACt: Changing the Focus?}

It goes without saying that the $\mathrm{ACA}^{224}$ was expressly designed to address many perceived shortcomings in the U.S. health care delivery system. Generally speaking, the current system has been viewed as competitive (in an unhelpful way), ${ }^{225}$ fragmented, and driven by

219 See id. at 356.

220 See id. at 397.

221 See Greaney \& Boozang, supra note 54, at 36.

222 See id. at 36-39.

223 See infra Section IV(A)(3)(a).

224 "On March 23, 2010, Congress enacted the Patient Protection and Affordable Care Act (PPACA). . . . Congress, recognizing there were a number of provisions in the PPACA that needed further refinement, enacted the Health Care and Education Reconciliation Act of 2010 (HCERA) on March 30, 2010. Together, PPACA and HCERA are referred to as the Affordable Care Act. On June 28, 2012, the Supreme Court upheld the PPACA, holding that it is constitutional." Medicare Certified Accountable Care Organizations, in 2013 HeAlth LAW AND COMPLIANCE UPDATE 1 (John Steiner ed., 2013).

225 "Unhelpful" in the sense that physicians have increasingly come to compete with hospitals to provide such things as ambulatory surgery centers and various advanced technologies and diagnostics-resulting in 
counterproductive financial incentives. ${ }^{226}$ These features have resulted in growing concerns over poor quality, spiraling costs, and rising barriers to access-all issues that have been thoroughly addressed and documented elsewhere. There is seemingly broad consensus, professional and academic if not political, that the solution lies with transition to an "integrated and coordinated care model" that is predicated upon "systems-based care management" that will consistently produce efficient, high quality services through greater collaboration among system participants. 227 While this new focus is readily described, it is somewhat more complicated to bring about, constituting what some have called a "battle for the soul of American medicine," 228 as well as the "biggest transformation of government since World War II."229 Moreover, it involves far more than simply modifying the "broad, complex, and indirect regulatory approaches that inevitably have unintended consequences"230_it involves quite literally reforming the entire health care system. ${ }^{231}$ Although such reform encompasses innumerable individual changes, at least three "cornerstone" themes are usually acknowledged: accountability, efficiency, and quality. ${ }^{232}$ To

"over-utilization, higher complication rates, and escalating charges." See Robin Locke Nagele, Hospital-Physician Relationships After National Health Reform: Moving From Competition to Collaboration, 82 PA. B. Ass'N. Q. 1, 2 (2011).

226 See generally id. at 1-3.

227 See id. at 1-2, 11.

228 See id. at 2.

229 See Gary S. Davis \& Michael L. Silhol, Healthcare Reform: The Law and Its Implications, 20101206 AHLA Seminar Papers 24 (2010) at p. 98 (citing Jackie Calmes, After Health Care Passage, Obama Pushes to Get It Rolling, N.Y. Times, Apr. 18, 2010, at A16 (quoting David Cutler, Harvard economist and President Obama's chief campaign adviser of health policy.).

230 For example, fraud and abuse laws and regulations that become significant obstacles to the adoption of "potentially cost-reducing or quality-enhancing innovation." See Kristin Madison, Rethinking Fraud Regulation by Rethinking the Health Care System, 32 Hamline J. Pub. L. \& POL'Y 411, 415-16 (2011).

231 Seeid. at $416-17,427$.

232 See Anne P. Sharamitaro, Healthcare Reform: Impact on Hospitals, 4 HEALTH CAPITAL TOPICS, 1, 1 (2011) archived at 
this can be added the additional theme of value, as discussed further in Section IV(A)(4) infra.

While it is difficult to summarize legislation that runs to approximately 2,400 pages, ${ }^{233}$ it is useful to look at the Act's overall framework. At the outset, it should be noted that the ACA amends several other existing statutes: the Public Health Service Act (PHSA), the Fair Labor Standards Act (FLSA), the Social Security Act (SSA), the Internal Revenue Code (IRC), the Employee Retirement Income Security Act of 1974 (ERISA), and the Deficit Reduction Act of 2005 (DRA). ${ }^{234}$ The ACA itself is divided into ten separate Titles:235 Title I - Quality, Affordable Health Care for All Americans; Title II - Role of Public Programs; Title III Improving the Quality and Efficiency of Health Care; Title IV- Prevention of Chronic Disease and Improving Public Health; Title V - Health Care Workforce; Title VI Transparency and Program Integrity; Title VII - Improving Access to Innovative Medical Therapies; Title VIII - CLASS Act;236 Title IX - Revenue Provisions; and, Title XStrengthening Quality, Affordable Health Care for All Americans. Collectively, these Titles affect almost every part of the health care system. ${ }^{237}$

For the purposes of this article, only those sections most relevant to the issues under discussion are listed and briefly described below:

\section{Title IX, § 9007}

The Act adds a new Section 501(r) to the IRC, including new community benefit requirements that nonprofit hospitals must meet to maintain their tax-exempt status

http://perma.cc/TU2P-KKN7.

233 Kurt Manwaring, How Many Pages Are in the Affordable Care

Act? KuRT's PERSPECTIVE (Aug. 5, 2011, 10:49 PM), http://kurtsperspective.blogspot.com/2011/08/how-many-pages-are-inaffordable-care.html.

234 Davis \& Silhol, supra note 229, at 99.

235 Id. at 99-100.

${ }^{236} I d$. at 99 n.7 ("Title VIII is a voluntary, national long-term care insurance program.”).

237 Id. at 99. 
under IRC Section 501(c)(3). ${ }^{238}$ (See Section IV(A)(3)(a) infra.)

Title VI, $\S \S 6001,6002,6401,6402 \& 6409$; Title X, § 10606

Several new anti-fraud and payment program initiatives are added by the Act, including (among other things) new transparency requirements governing the relationships between and among drug and device companies, physicians, and teaching hospitals.239 Significantly, § 6001 has eliminated the "whole hospital exception" of the Stark Law. 240

Title I, §§ 1001, 1101, 1201, 1251, $1301 \& 1311$; Title X, §§ $10101 \& 10103$ HCERA, ${ }^{241} \S \S 1102 \& 1103$

These sections collectively reform many aspects of the health insurance market, including: "new requirements related to underwriting, scope of benefits, and rating;" establishing Medical Loss Ratio (MLR) requirements; expansion of coverage to "dependents up to age 26"; "elimination of pre-existing condition exclusions"; and the cost-sharing requirements by health plans for emergency services. Of greatest significance, these sections establish the "state-based insurance exchanges" and mandate "guaranteed issue and guaranteed renewal" of coverage in the entire private insurance market. ${ }^{242}$

\section{Title III, $\S \S 3001,3008 \& 3025$}

A major priority of the Act is to motivate hospitals to improve quality through Medicare payment adjustments in response to various performance measures. To this end, the Act establishes new programs covering such things as value-based purchasing, payment adjustments for hospital-

238 See id. at 80-81.

239 See id. at 84.

240 See Nagele, supra note 226, at 9.

241 The Health Care and Education Reconciliation Act of 2010.

242 Davis \& Silhol, supra note 229, at 86. 
acquired conditions, and hospital readmissions reduction. ${ }^{243}$

Title I, § 1311; Title II, §§ 2702, $2717 \& 2718 ;$ Title III, §§ $\underline{3001,3002,3011,3012,3021,3023,3501 \& 3502 ;}$

Title VI, §6301

All of these sections deal, in one way or another, with the Act's objective of motivating development of the health information technology (HIT) infrastructure necessary to support the coordination of care, quality measurement and reporting, and new payment models. Such infrastructure is also seen as essential to the continued progress of biomedical research and the eventual implementation of personalized medicine. ${ }^{244}$

Title II, §§ 2704, 2705 \& 2706; Title III, \$\$ 3001, 3021, $\underline{3022,3023,3025,3027 \& 3502 \text {; Title X, \$\$ } 10307 \& 10333}$

Under the Act, significant cuts will be made in Medicare and Medicaid (estimated to be $\$ 330$ billion). Various provisions under the above sections are designed to "shift the payment system from traditional fee-for-service (FFS) to budgeted (e.g., shared savings, bundled payments based on episodes of care, capitation) or value-based (e.g., pay-forperformance) payment models." A key initiative under this effort is the development of Accountable Care Organizations (ACOs). (See Section $\operatorname{IV}(\mathrm{A})(4)(\mathrm{a})$ infra.) ${ }^{245}$

\section{A. How Will New ACA Imperatives Affect the Traditional Organizational Forms?}

Obviously, the above-described imperatives will significantly impact the way all hospitals operate in the future. In some cases, it is clear that the effect will differ depending on the hospital's organizational form. The most obvious example (discussed in Section $\operatorname{IV}(\mathrm{A})(3)(\mathrm{a})$ infra) is the new community benefit requirements that apply only to

\footnotetext{
243 Id. at $87-88$.

244 Id. at 90.

245 Id. at 91 .
} 
nonprofits. It is less obvious, or currently speculative, whether other imperatives will differentially impact nonprofit and for-profit organizations. What is clear is that the operating environment is changing, with new demands challenging organizations' historical attitudes about the sufficiency of their size and market position. ${ }^{246}$ As Davis and Silhol have noted:

$[\mathrm{M}]$ any have recognized that growth and scale are critical to meeting the new cost, quality and reporting obligations that will be imposed upon them. In light of this, an increasingly important aspect of an institution's strategy will be the active consideration of mergers, acquisitions, member substitutions, joint ventures opand clinical affiliations with other hospitals, health systems and academic medical centers. ${ }^{247}$

The sections that follow attempt to discern how organizational form may affect, and be affected by, these challenges.

\section{Industry Consolidation}

As discussed in Section II(B) supra, the hospital industry has gone through prior periods of consolidation, largely precipitated by the advent of third-party and governmental payors and the development of both nonprofit and for-profit systems. Many experts foresee the ACA resulting in yet another period of consolidation. ${ }^{248}$ In addition to significantly expanding the number of insured patients, the ACA will bring new reimbursement models designed to

246 Id. at 96.

247 Id. (emphasis added).

248 See Samuel R. Maizel and Mary D. Lane, The Sale of Nonprofit Hospitals Through Bankruptcy: What BAPCPA Wrought, 30 AM. BANKR. INST. J. 12, 73 (2011) (citing The Impact of Healthcare Reform on Hospital Consolidation, BACKER's Hospital ReVIEw (Sept. 16, 2010) ("[H] ealthcare reform will affect hospital consolidation in three ways: by decreasing revenues, increasing costs and rewarding integration.”)). 
incentivize the provision of more integrated and coordinated care. ${ }^{249}$ Pressures to consolidate will be particularly acute for financially distressed, unaffiliated hospitals and small systems-most of which are nonprofits. ${ }^{250}$ For many of these organizations, merger with a larger nonprofit system or sale to a for-profit chain may be the only option to improve their operating margins, ensure continued access to credit and capital, acquire and implement information technology, and otherwise develop necessary efficiencies of scale and coordination - all foreseeably required to meet the new imperatives of the ACA. ${ }^{251}$

\section{a. The demise of physician-owned, specialty hospitals}

For-profit, physician-owned, specialty hospitals are one type of facility whose fate under the ACA is not uncertain. As previously discussed, ${ }^{252}$ by the year 2010 such facilities were coming under intense criticism for such perceived failings as: having disproportionately higher costs (largely due to compensation mechanisms that promoted overutilization by practicing physician-owners with financial conflicts of interest); failing to care for uninsured, severely ill, or otherwise unprofitable patients; and, jeopardizing patient safety by operating without on-site emergency departments. ${ }^{253}$

With $\S 6001$ of the ACA having eliminated the "whole hospital exception" of the Stark Law and having placed several new restrictions on currently operating facilities, ${ }^{254}$ the era of the physician-owned, specialty hospital appears to be over. It remains to be seen whether existing facilities will continue to operate with the new restrictions, or will simply liquidate or sell to other traditional institutional providers.

249 Davis \& Silhol, supra note 229, at 111.

250 See Zall \& Kinsella, supra note 61 , at 11.

251 See id.

252 See supra Section II(B)(2).

253 Perry, supra note 67 , at 1.

254 Id. at $40-43$. 


\section{The Growing Importance of Capital}

As Stewart and Smith note:

The delivery of 21st century health care services in the United States is an increasingly capital intensive enterprise . . . . The need to replace and renovate aging facilities and a growing demand for new diagnostic and treatment equipment driven by a rapidly advancing medical technology increases demand for capital financing. Furthermore, the escalating need for large investments in information technology required to implement fully integrated electronic health records (EHRs) and computerized provider order entry systems (CPOEs) also create a demand for significant capital financing. ${ }^{255}$

Since the time that charitable, nonprofit hospitals first became commercial, fee-charging businesses comparable to their for-profit counterparts, it has been debatable which corporate form has better access to necessary capital. A simple analysis begins with consideration of the four commonly used sources of available capital: taxable bonds, tax-exempt bonds, charitable contributions, and stock. ${ }^{256}$

Some believe that charitable nonprofits have the advantage by virtue of their access to tax-exempt bonds and tax-deductible charitable contributions-both of which contribute to a lower "weighted average cost of capital" (WACC). 257 Moreover, nonprofits have benefited in recent

255 Louis J. Stewart \& Pamela C. Smith, An Examination of Contemporary Financing Practices and the Global Financial Crisis on Nonprofit Multi-Hospital Health Systems, 37 J. Health Care Fin. 1, 124 (2011).

256 Schirra, supra note 30 , at 252.

257 WACC is the weighted average of the component costs of capital. It is less for charitable nonprofits because (1) the interest payable on tax-exempt bonds is less (than on taxable bonds) due to the interest received by the bondholder being non-taxable, and (2) donations to taxexempt nonprofits are tax-deductible by the donor. See generally id. at 
years from the previously described practice of tax arbitrage, ${ }^{258}$ which enables them to retain more of their net earnings for application to capital needs. In addition, nonprofits are more likely to receive governmental grants and private foundation funding. 259 The downside of nonprofits' position, however, is their necessary reliance on tax-exemption for these advantages. Clearly, a loss of taxexemption would be disastrous for most nonprofits.

Others believe that the cost of capital is not as important as access to capital. In this regard, for-profit hospitals have many more ways to raise capital than do nonprofits. ${ }^{260}$ Foremost among them, of course, is the issuance of stock to investors looking for a return on investment from share appreciation (i.e., capital gains) or dividends. ${ }^{261}$ More broadly speaking, however, for-profits are free to engage in all manner of capital-raising devices foreclosed to nonprofits by the "private inurement doctrine" 262 - e.g., private bond markets, mortgages, capital leases, secured loans, real estate investment trusts, etc. ${ }^{263}$ In addition, one can reasonably expect a greater willingness by venture capitalists to work with for-profits, since they do not have to contend with the private inurement constraint.

\section{A Diminishing Need for Charity Care}

"If, as a result of health care reform, everyone has health insurance, presumably hospitals should see a steep decline in, or the elimination of, uncompensated care .... Given

251-253.

258 See supra Section III(B).

259 Schirra, supra note 30, at 261.

$260 I d$. at 262.

261 Id.

262 "Private inurement occurs whenever persons having a personal and private interest in a nonprofit hospital receive benefits disproportionate to their contributions to the entity." Id. at 245 (citing Treas Reg. § 1.501(a)-1(c) (West 2011)).

263 Robert J. Cimasi \& Anne P. Sharamitaro, Value Metrics and Capital Formation for Accountable Care Organizations, 15 VALST 6, 13 (2012). 
this trend, does it make sense to retain taxexemption for hospitals?"264

Following the implementation of Medicare and Medicaid, there was a similar expectation that hospitals would be confronted with less need to provide uncompensated care. ${ }^{265}$ Not surprisingly, arguments very similar to Senator Grassley's were likewise raised when the IRS subsequently proposed to "transition from a 'charity care' standard to a 'community benefit' standard under Section 501(c)(3)."266

Under the ACA, it is expected that the need for charity care will be further reduced through two primary mechanisms: (1) implementation of the individual mandate to buy insurance (with available federal subsidies where appropriate) and development of the "health insurance exchanges" (HIXs) to facilitate people doing so; and, (2) state expansion of Medicaid eligibility to now cover "adults with incomes up to $138 \%$ of the federal poverty level ("FPL")."267 Although initially required as part of the ACA, state participation in the Medicaid expansion was made optional for the states by the U.S. Supreme Court decision in National Federation of Independent Business $v$. Sebelius. ${ }^{268}$

According to Dorn et al., even if no state participates in Medicaid expansion, the ACA will still result in a $28 \%$ reduction in the number of uninsured by 2022 by means of the Act's "[n]ew subsidies in HIXs, individual coverage

264 Katie Stewart \& Darren Azman, Section 501(r) and Nonprofit Hospital Joint Ventures, 22 TAXATION OF EXEMPTs 9 (citing Roundtable Discussion on Comprehensive Healthcare Reform: Hearing Before the $S$. Comm. on Fin., 111th Cong. 118 (2009) (statement of Sen. Charles E. Grassley)).

265 Id.

266 Id. (citing Staff of The S. CoMm. ON Fin., 91St Cong., Medicare and Medicaid: Problems, Issues, and Alternatives 56 (Comm. Print 1970)).

267 See generally Stan Dorn, et al., The Financial Benefit to Hospitals from State Expansion of Medicaid, TIMELY ANALYSIS OF IMMEDIATE HEALTH POLICY ISSUES (2013), available at http://www.rwjf.org/content/dam/farm/reports/issue_briefs/2013/rwjf405 040.

268132 S. Ct. 2566 (2012). 
requirements, incentives for employer-sponsored coverage, and streamlined enrollment methods." 269 If all states participate, then the number of uninsured will be reduced by $48 \% .270$ The intuitive fact that the uninsured generate more uncompensated care than the insured has been demonstrated by Hadley et al. ${ }^{271}$ This has been confirmed by the experience in Massachusetts, where 2006 health reforms that reduced the number of uninsured resulted in a near $40 \%$ reduction in uncompensated care costs in the first year. 272

However, as Schirra notes, "there will still be approximately fourteen million uninsured Americans, not including illegal aliens, after full implementation" of the ACA. ${ }^{273}$ The question becomes whether nonprofits' current level of tax-exemption can continue to be justified after such a reduction in the need for charity care?

\section{a. Additional regulatory burdens on nonprofits}

The new community benefit requirements set forth in ACA $\S 9007$ resulted from the many recent criticisms of nonprofits previously discussed, as well as the expected reduction in the need for uncompensated care under the Act. ${ }^{274}$ In fact, the provisions of $\S 9007$ (with one exception) closely follow the May 2009 Senate Finance Committee proposal $^{275}$ submitted by Senators Grassley and Baucus. ${ }^{276}$

269 Dorn et al., supra note 267 , at 4.

270 Id.

271 Id. (citing Hadley J. et. al., Covering the Uninsured in 2008: Current Costs, Sources Of Payment, And Incremental Costs, HealTH AFFAIRS, 27(5): w399-w415, 2008).

272 See id. (citing 2009 Annual Report - Health Safety Net, Boston: Massachusetts Division of Health Care Finance and Policy; Access to Health Care in Massachusetts: Results .from the 2008 and 2009 Massachusetts Health Insurance Survey, Boston: Massachusetts Division of Health Care Finance and Policy, 2009).

273 See Schirra, supra note 30, at 274.

274 See Michael N. Fine \& Christopher M. Jedrey, "Show Me The Money": Maintaining Hospital Tax-Exempt Status, 22 TAXATION OF Exempts 3 (2010).

275 See supra Section III(B)(1).

276 Fine, supra note 274, at 5. (The biggest difference is that the Act 
Under the ACA's corresponding new $\S 501(\mathrm{r})$ of the Internal Revenue Code, ${ }^{277}$ obtaining or retaining tax exempt status now requires that hospitals:

1. establish written policies regarding patient eligibility for financial assistance and the provision of emergency care;

2. limit the amount charged to patients eligible for financial assistance for emergency or medically necessary care to the amount generally billed for insured patients;

3. refrain from pursuing "extraordinary collection actions" without first inquiring whether a patient is eligible for financial assistance; and,

4. at least once every three years, conduct a "community health needs assessment" and adopt an 'implementation strategy' to respond to the needs identified by the assessment. 278

doesn't require a minimum level of charity care. $I d$. at 6).

277 See Mary Crossley, Tax-Exempt Hospitals, Community Health Needs and Addressing Disparities, 55 How. L.J. 687, 692 (2012) (citing PPACA, Pub. L. No. 111-148, § 9007(a), 124 Stat. 119, 855-57 (2010), amended by PPACA, Pub. L. No. 111-148, § 10903(a), 124 Stat. 119, 1016 (codified at 26 U.S.C. $\S 501(\mathrm{r})$ (and re-designating existing $\S 501(\mathrm{r}$ ) as $\S 501(\mathrm{~s})))$.

$278 I d$ at 693. Crossley provides a good, concise summary of the specific requirements of the CHNA: "[A] hospital must conduct a CHNA ... taking into account input from persons who represent the broad interests of the community served by the hospital facility, including those with special knowledge of or expertise in public health.' Once the CHNA has been completed, the hospital must make the assessment 'widely available to the public.' Then the hospital must adopt an 'implementation strategy to meet the community health needs identified through such assessment,' and, finally, it must report to the IRS 'how the organization is addressing the needs identified' and 'a description of any such needs that are not being addressed together with the reasons why such needs are not being addressed.' By establishing this multistep process, the ACA seeks to ensure that tax-exempt hospitals are in fact providing community benefits by requiring them first to assess what specific health needs their communities have, then to take steps to 
Nonetheless, Fine and Jedrey note that tax-exempt hospitals are still obliged to "seek payment for services" from non-paying patients or risk "violating certain Medicare and Medicaid billing requirements." 279 In any event, the breadth and complexity of these new regulatory requirements will clearly add to the burden and compliance cost for tax-exempt, nonprofit hospitals-a burden and cost not imposed on their for-profit counterparts.

\section{Cornerstone Themes: Quality, Value, Efficiency, and Accountability}

As previously noted, while the ACA's systemic reform of health care delivery involves innumerable individual changes, a focus on quality, value, efficiency, and accountability are central to addressing the current system's acknowledged problems with poor quality, spiraling costs, and rising barriers to access. To this end, more than anything else, federal health care payments will be transitioned from "payment for volume" to "payment for quality."280 Much of this effort will be accomplished through a variety of new programs found in Title III of the Act:

- The Hospital Value-Based Purchasing Program (a mandatory program), ${ }^{281}$

- the Payment Adjustment for Conditions Acquired in Hospitals (a mandatory program), ${ }^{282}$

meet those needs, and, finally, to report what they are doing to the IRS. A tax-exempt hospital that fails to comply with these requirements will be subject to a $\$ 50,000$ excise tax." Id. at 693 .

279 Fine and Jedrey, supra note 274, at 6.

280 See Christi J. Braun \& Michelle D. Johnson, Provider Alignment for Quality and Payment: New Takes on Old Ideas (2010).

281 The Affordable Care Act, Pub. L. No. 111-148, 124 Stat. 119 (2010) (to be codified as amended in scattered sections of 21, 25, 26, 29, and 42 U.S.C.). See also Title III, Part 1: Linking Payment To Quality Outcomes Under The Medicare Program, § 3001, available at http://www.gpo.gov/fdsys/pkg/PLAW-111publ148/pdf/PLAW-

111publ148.pdf.

$282 I d$. at $\S 3008$. 
- the Physician Quality Reporting Initiative (a mandatory program), ${ }^{283}$

- the Value-Based Physician Payment Modifier (a mandatory program), 284

- the Hospital Readmissions Reduction Program (a mandatory program), 285

- the Medicare Shared Savings Program (a voluntary program), 286 and

- the Payment Bundling Pilot Program (a demonstration program). ${ }^{287}$

While a detailed description of each of these programs is beyond the scope of this article, the focus of most of them is self-evident from their titles. One exception is the Hospital Value-Based Purchasing Program, wherein participating hospitals will receive incentive payments for meeting or exceeding certain CMS-designated performance benchmarks, including metrics of quality, efficiency and patient satisfaction. ${ }^{288}$ These metrics will initially address treatment and outcomes for such clinical conditions as pneumonia, heart failure, and hospital-acquired infections, with other conditions to be added later. ${ }^{289}$ Another exception that merits further discussion is the development of Accountable Care Organizations (ACOs) under the Medicare Shared Savings Program (MSSP), since this program is expected to give rise to new organizational structures. ${ }^{290}$

\section{a. ACOs: Alignment and integration of multiple stakeholders}

Section 3022 of the Affordable Care Act amends Title XVIII of the Social Security Act

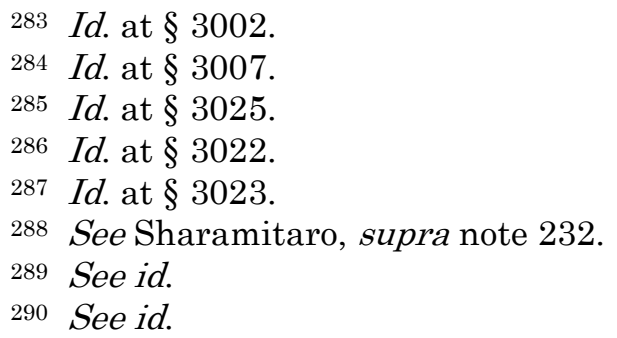


(SSA) (42 U.S.C. 1395 et seq.) . . . to establish a Medicare shared savings program that promotes accountability for care of Medicare beneficiaries, improves the coordination of Medicare fee-for-service items and services, and encourages investment in infrastructure and redesigned care processes for high quality and efficient service delivery. Under [new] § 1899(b)(1) of the SSA, groups of health care service providers and suppliers that have established a mechanism for shared governance and that meet criteria specified by HHS are eligible to participate as ACOs under the program. ${ }^{291}$

ACOs are among the key strategies under the ACA to improve quality and lower cost by promoting organizational structures that will coordinate and integrate the care provided by different service providers in various settings. ${ }^{292}$ Participating providers ${ }^{293}$ will assume overall responsibility for controlling the quality and cost of care for a defined population of patients. ${ }^{294}$ The providers will then partner with payors to create incentives for the delivery of care of higher quality and

291 IRS Notice 2011-20, Background on ACOs And The MSSP, at 1, available at: http://www.irs.gov/pub/irs-drop/n-11-20.pdf.

292 See Kristin L. Reiter \& Paula H. Song, Hospital Capital Budgeting in an Era of Transformation, 39 J. HeAlth CARE Fin. 14 (2013).

293 "[t]he following groups of providers of services and suppliers which have established a mechanism for shared governance are eligible to participate as ACOs under the program under this section: (A) ACO professionals in group practice arrangements. (B) Networks of individual practices of ACO professionals. (C) Partnerships or joint venture arrangements between hospitals and ACO professionals. (D) Hospitals employing ACO professionals. (E) Such other groups of providers of services and suppliers as the Secretary determines appropriate." Patient Protection and Affordable Care Act, Pub. L. No. 111- 148, 124 Stat. 119 (2010) (codified in scattered sections of 42 U.S.C.), Title III, Part 3 - Encouraging Development Of New Patient Care Models, § 3022.

294 Reiter \& Song, supra note 292, at 14. 
lower cost than customary under fee-for-service, using flexible forms of reimbursement that may include "shared savings programs," penalties, and various forms of capitation. 295

One of the most interesting features of ACOs is the enhanced involvement of multiple "stakeholders," including both individual professionals (e.g., physicians) and institutions (e.g., hospitals, group practices, payors, etc.). By design, the ACA has not specified any particular legal or organizational form through which these multiple stakeholders are to accomplish the requisite "shared governance" of the ACO.296 At present, the ACO itself can be a nonprofit corporation, a for-profit

295 Id. at $14-15$.

296 "Section $1899(\mathrm{~b})(2)$ of the SSA establishes the following requirements for an ACO to participate in the program: (1) The ACO shall be willing to become accountable for the quality, cost, and overall care of the Medicare fee-for-service beneficiaries assigned to it. (2) The ACO shall enter into an agreement with the HHS Secretary to participate in the program for not less than a 3-year period (the MSSP agreement period). (3) The ACO shall have a formal legal structure that would allow the organization to receive and distribute payments for shared savings under $\S 1899(\mathrm{~d})(2)$ to participating providers of services and suppliers. (4) The ACO shall include primary care ACO professionals that are sufficient for the number of Medicare fee-for-service beneficiaries assigned to the ACO under $\S 1899(\mathrm{c})$. At a minimum, the ACO shall have at least 5,000 such beneficiaries assigned to it under $\S 1899(\mathrm{c})$ in order to be eligible to participate in the MSSP. (5) The ACO shall provide the HHS Secretary with such information regarding ACO professionals participating in the ACO as the Secretary determines necessary to support the assignment of Medicare fee-for-service beneficiaries to an ACO, the implementation of quality and the other reporting requirements under $\S 1899(\mathrm{~b})(3)$, and the determination of payments for shared savings under $\S 1899(\mathrm{~d})(2)$. (6) The ACO shall have in place a leadership and management structure that includes clinical and administrative systems. (7) The ACO shall define processes to promote evidence-based medicine and patient engagement, report on quality and cost measures, and coordinate care, such as through the use of telehealth, remote patient monitoring, and other such enabling technologies. (8) The ACO shall demonstrate to the HHS Secretary that it meets patient-centeredness criteria specified by the Secretary, such as the use of patient and caregiver assessments or the use of individualized care plans." IRS Notice 2011-20, Background on ACOS And The MSSP, at 2. 
corporation, some other type of legal business entity (e.g., limited liability company, partnership, etc.), or even some type of contractual joint venture-so long as all other statutory (and eventually regulatory) requirements are met. Needless to say, however, if tax-exempt nonprofits participate in an ACO, they must be concerned (at least for now) with the possibility that their involvement will run afoul of the private inurement doctrine. In this regard, Johnson and Moroney have noted:

In Notice 2011-20 (03/31/11), the IRS announced that, under certain conditions, ${ }^{297}$ it generally would not consider a tax-exempt organization's participation in the MSSP through an ACO to result in inurement or substantial private benefit. ... . [T]he IRS stated its expectation that MSSP payments would be derived from activities that are substantially related to the performance of the charitable purpose of lessening the burdens of government within the meaning of Treas. Reg.

297 "The IRS said that due to the Centers for Medicare and Medical Services (CMS) oversight in the compliance and eligibility for participation of ACOs in the MSSP program [a joint venture ACO] [sic] would not 'generally' result in prohibited inurement or private benefit if the following guidelines were met:

- The term of the tax-exempt organization's participation (including its share of MSSP payments) are set forth in advance in writing and negotiated at arm's length.

- CMS has accepted the ACO into the MSSP.

- The tax-exempt entity's share of economic benefits from the ACO is proportional to the benefits or contributions provided to the ACO by the tax-exempt entity. If the tax-exempt entity receives an ownership interest in the ACO, the amount of its capital contributions must be proportional and equal in value to its ownership interest and distributions must be made in proportion to ownership interests.

- The tax-exempt entity' s share of the ACO's losses doesn't exceed its share of the economic benefits.

- All transactions among the tax-exempt entity and the ACO (or its participants) must be fair market value."

Milton Cerny \& Barton C. Walker, Nonprofit Healthcare: What Does the Future Hold?, (MCGUIRE WoODs LLP), 2011, at 6., archived at http://perma.cc/89BU-RLWX. 


\begin{abstract}
$\S 1.501(\mathrm{c})(3)-1(\mathrm{~d})(2) . \ldots$
'Congress established the MSSP to be conducted through ACOs in order to promote quality improvements and cost savings, thereby lessening the government's burden associated with providing Medicare benefits.' . . . The IRS cautioned, however, that not every activity that promotes health is considered to be a charitable purpose. Accordingly, $A C O$ arrangements entered into outside the MSSP (e.g., with commercial payors) are unlikely to lessen the burdens of government and conceivably may not further any other charitable purposes. ${ }^{298}$
\end{abstract}

The last sentence above makes an important point worth emphasizing: while the ACA has in a sense "created" the ACO under the MSSP, the law does not require all ACOs to participate in the MSSP. That is to say, the ACA does not prohibit the development of "private" ACOs, which are free to organize and operate independent of the Medicare Program. In theory, at least for now, such ACOs could operate entirely as for-profit enterprises relying solely on reimbursement from non-governmental, third-party payors (which appears to be increasingly happening, with several major insurers partnering with ACOs to serve purely "commercial" enrollees in markets throughout the U.S.).

Regardless, all prospective ACOs at present are confronted with the uncertainty of how the various fraudand-abuse and antitrust regulators ${ }^{299}$ will react to their efforts to achieve the financial and clinical integration necessary for success. 300 One of the ironies of health care reform is the direct conflict between the ACA's focus on

298 Tricia M. Johnson \& Linda S. Moroney, Tax Issues for Healthcare Organizations, 20111002 AHLA SEMINAR PAPERS 63, at 29 (2011) (emphasis added).

299 For example, the Center for Medicare and Medicaid Services (CMS), the Office of Inspector General (OIG), the Department of Justice (DOJ) and the Federal Trade Commission (FTC). See Nagele, supra note 226 , at 2 .

300 See Nagele, supra note 226, at 1-2. 
integration and coordination of multiple system participants, and the historic prosecution of such activities under the anti-trust, Stark and Anti-Kickback laws.

Finally, Reiter and Song identify three particularly significant challenges facing hospitals engaged in ACO development:

- "managing the priorities of a broad range of stakeholders;

- thriving in a payment environment driven by value rather than volume; and

- finding sufficient capital to allocate to IT."301

\section{B. Is the ACA's Focus Compatible with Commercialized Medicine?}

As Perry has noted, the "forces of commercialization" in health care have "coalesced to create a powerful $\$ 2.5$ trillion industry that, in 2009 , constituted greater than $17 \%$ of the nation's economy." 302 These forces of course include more than just doctors and hospitals-they include health insurers, health care manufacturers and suppliers, pharmaceutical companies, all manner of other individual health care professionals who serve patients directly, and other non-health care professionals and industries providing support to the health care sector in general. Many if not most of these other participants are for-profit companies, which, in their efforts to maximize profits, also help the economy by providing jobs and exports. ${ }^{303}$ It is this entire "web" of participants (as well as advances in medical science and technology) that has commercialized health care delivery in the United States. If the ACA is to succeed, it will have to do so in this context-a now unalterable fact of modern health care economics.

The question therefore is: how does one provide the public good of, or right to, high-quality, high-value health

301 Reiter \& Song, supra note 292, at 20.

302 Perry, supra note 2, at 54.

303 See Kinney, supra note 82, at 419. 
care in a competitive, free-market economy? The ACA's answer (to the dismay of many) was not through a government-operated, single-payor system. Had the ACA taken that approach-paying for health care services out of general revenues as a matter of right for all Americans-the conflicting objectives and divergent characteristics of nonprofit and for-profit hospitals would likely diminish if not disappear entirely over time: that is, tax-exempt status would become irrelevant since there would be no need for charity care; the problem of nonprofits being too aggressive in mimicking for-profits' business practices would be a nonissue since all hospitals would ostensibly operate under the same rules to accomplish the same ends; and, "unhelpful" inter-institutional competition would probably lessen since there would be little opportunity to obtain a differential advantage, at least financially. Instead, however, the ACA took an approach based upon the "managed competition" model of the 1990s as developed by Alain Enthoven of Stanford University. ${ }^{304}$ That model reflects "a blending of competitive and regulatory strategies that must co-exist in the healthcare industry and which aim to achieve maximum value for both consumers and providers." 305 The model represents a compromise "springing from a belief that healthcare is both a right and an obligation . . . i.e., that people have a right to access and an obligation to pay for their portion." 306

The ACA's framework also follows an approach to health care reform that was developed in Massachusetts and enacted there in 2006. ${ }^{307}$ The framework builds upon what Kirsch characterizes as "the four pillars of the current health care coverage system: employer provided coverage, Medicaid, Medicare, and individually purchased insurance." 308 Like the Massachusetts legislation, the ACA

304 See Cimasi and Sharamitaro, supra note 263, at 7.

305 Id. at 8 (citing Enthoven, The History and Principals of Managed Competition, 12 HeAlTh AFFaIRS SUPP. 24 (1993)).

306 Id. (citing Morrison, The New American Compromise, $61 \mathrm{H} \& \mathrm{HN}$ 32 (September 2008)) (emphasis in original).

307 See Kirsch, supra note 3, at 1741.

$308 I d$. 
incorporates a compromise innovation first promoted by the conservative Heritage Foundation-an individual mandate to obtain coverage that is provided through a "marketplace" of private health insurance (i.e., the "exchanges"). 309 This is clearly a "commercialized" approach, notwithstanding a degree of government involvement. As Grogan aptly summarizes it:

Under the ACA ... the government (state and federal) will (1) determine the basic benefit package that all health insurance plans must provide to participate in the insurance exchange; (2) more heavily regulate private insurance companies, including barring actuarial risk rating when setting premiums; and (3) provide public subsidies for some families to purchase private health insurance on the exchange. In light of these responsibilities, it is clearly farcical to label the new health insurance arrangements predominantly private. But the government is also so completely dependent on private actors-from hospitals, providers, and pharmaceutical companies to private insurance companies - to get the whole thing to work, that one can hardly call the ACA a government takeover. It is a two-way dependency. 310

\section{A New Organizational Paradigm}

Under the ACA approach, delivery system participants remain disparate-some will pursue profit-maximization, others will pursue the public good. Yet, as previously noted, the fundamental purpose of the ACA is to transform the current fragmented delivery system into an integrated and coordinated care model that consistently produces improved

309 See id.

310 Colleen M. Grogan, You Call It Public, I Call It Private, Let's Call The Whole Thing Off?, 36 J. HeAlth POL. Pol'Y \& L. 401, 403 (2011) (emphasis added). 
quality, greater accessibility, and lower cost. ACOs are central to this effort by virtue of their specific intent to effect greater collaboration between and among these disparate system participants. However, such collaboration will necessarily remain hindered by the conflicting organizational objectives inherent in the nonprofit versus for-profit dichotomy. What may be needed now is a new organizational paradigm.

\section{A. The Need for Mission Primacy}

Some have argued that the concept of "mission primacy"-a "doctrinal recognition" that a corporation's "articulated mission" should be its legally-enforceable primary objective (as is profit-maximization for a for-profit corporation) ${ }^{311}$ - should be more strictly applied to taxexempt, nonprofit health care corporations in order to better ensure director fidelity to the organizations' charitable missions. ${ }^{312}$ This approach appears warranted in view of the significant evidence that threatened loss of taxexemption is, by itself, insufficient to ensure that nonprofits provide an appropriate and expected level of public benefit. ${ }^{313}$ As Greaney and Boozang explain:

As a general guiding principle, we suggest that "mission primacy" should be recognized as a central objective of the nonprofit enterprise ... - This focus would incorporate missioncentered values into interpretations of the traditional fiduciary duties of care and loyalty. At the same time, like the model of "director primacy" advanced for proprietary corporations, it would preserve managerial discretion to balance the various constituents of the nonprofit firm including donors, consumers, and the community. Consequently, this standard would accommodate the

311 See discussion, supra Section III(D)(1).

312 See generally, Greaney and Boozang, supra note 54, at 5.

313 See id. at 6. 
relational imperatives of the modern business environment in health care. . . . Finally, mission primacy accounts for the particular circumstances of nonprofit governance because it preserves the central values of trust and volunteerism that are needed to reinforce legal duties. ${ }^{314}$

The recognition that mission objectives other than pursuit of profit are sufficiently important in health care to justify giving them more formalized legal status finds support in Robert G. Evans' concept of a "not-only-for-profit' sector"-a designation referring to "firms "in which a legal claimant to profits is well-defined, but profits represent only one among several competing objectives of the firm's ownership and management." 315 This designation seems particularly apropos to ACOs, the acknowledged purpose of which is to improve the value, quality, and efficiency of health care services, as well as accountability for their delivery. Pursuit of "profit"-in the sense of residual revenue over expenses necessary to meet ongoing capital needs for replacement and growth-would necessarily remain, but as a secondary rather than sole or even primary objective. Because accomplishing an ACO's purpose requires a significant degree of integration of, and collaboration among, different entities (nonprofit and for-profit alike), a new mission-centered form of health care organization specifically designed to serve the diverse objectives of multiple stakeholders makes sense, since the directors of such a new organization would have an explicit, legallyenforceable duty to take all mission considerations into full account in their business decision-making. ${ }^{316}$

314 Id. at 83-84 (emphasis added).

315 See Marmor, et al., supra note 12, at 319 (quoting Robert Evans, Strained Mercy: The Economics of Canadian Health Care at 127 (1984)) (emphasis added).

316 See Greaney \& Boozang, supra note 54, at 84. 


\section{Constituency Statutes}

Similar in purpose to this idea are what have variously been called "constituency," "stakeholder," or "nonshareholder" statutes-found (as of 2002) in 33 states. ${ }^{317}$ These statutes permit, but do not require, directors to make decisions based on considerations other than strictly shareholder interests. 318 The statutes then shield the directors from at least some personal liability for doing so. ${ }^{319}$ However, while such statutes may be a way to encourage corporations to balance the interests of multiple stakeholders, they have been largely discredited (at least in their current forms) for being discretionary and lacking any clear-cut enforcement mechanisms. ${ }^{320}$ Moreover, they have been used mostly in connection with takeover defenses, serving merely to entrench the interests of existing management rather than to defend the interests of other stakeholders. ${ }^{321}$ This has prompted Jonathan Springer, acknowledged to be the preeminent scholar on constituency statutes, to suggest: "[I]f there is any fundamental change in corporate law that will address constituency interests, it will be only as the result of a direct engagement of the legal and economic underpinnings of corporate law."322 That is, the norm of shareholder wealth maximization must be challenged outright. ${ }^{323}$

317 Briana Cummings, Benefit Corporations: How to Enforce a Mandate to Promote the Public Interest, 112 Colum. L. REv. 578, 587588 (2012) (citing Lisa M. Fairfax, Doing Well While Doing Good: Reassessing the Scope of Directors' Fiduciary Obligations in For-Profit Corporations with Non-Shareholder Beneficiaries, 59 WASH. \& LEE L. REV. 409, 460 n.285 (2002) (describing longstanding debate between shareholder and stakeholder theories)).

318 See Clarke, supra note 6, at 306-307.

319 Id. at 307.

320 Id.

321 Kanig, supra note 8, at 887.

322 Id. (quoting Jonathan D. Springer, Corporate Constituency Statutes: Hollow Hopes and False Fears, 1999 ANN. SuRV. AM. L. 85 (1999)).

323 Id. 


\section{B. Hybrid Legal Structures}

In recent years, a variety of new legal forms have been proposed to do just that. Under the general rubric of "hybrid legal structures," these new forms include "sociallyresponsible business corporations," "social enterprise" or "social entrepreneurship" organizations, and "not-for-loss corporations." 324 Most of these proposals have come from the "social entrepreneurship movement" of recent years that has promoted development of sustainable organizations designed to provide specific solutions to social problems. ${ }^{325}$ The organizations can take the form of either a businessoriented nonprofit or a mission-oriented for-profit. ${ }^{326}$ According to Clarke, these entities "tread[] against the very essence of the for-profit motive" 327 by defining stakeholder benefit as the primary purpose of the organization, in contravention of which the organization may not act. 328

In many ways, this brings the argument full circle and returns to the position of Edwin Merrick Dodd, who advocated for the "stakeholder theory of corporate governance." 329 It is ironic that Dodd argued during the "Great Depression" that "the corporation is a "social institution' . . . the byproduct of a bargain between the state and private actors to construct a vehicle for wealth creation that carries concurrent obligations to parties beyond its direct owners;" 330 whereas today, on the heels of the "Great Recession" and within the context of the ongoing debate over the ACA, Grogan argues that "the government is . . . so completely dependent on private actors-from hospitals, providers, and pharmaceutical companies to private insurance companies - to get the whole thing to work, that .

324 See generally Clarke, supra note 6.

325 See id. at 307.

326 See id.

327 Id. (quoting Jonathan D. Springer, Corporate Constituency Statutes: Hollow Hopes and False Fears, 1999 AnN. Surv. AM. L. 85 (1999).).

328 Id.

329 See supra Section III(D)(1).

330 See Kanig, supra note 8, at 875. 
.. [i]t is a two-way dependency." 331 As Yogi Berra said, "[t]his is like déjà vu all over again."

For the necessarily limited purposes of this article, the seemingly endless contours of this discussion will be confined to a brief characterization of the three most currently-prominent forms of hybrid legal structures: the "Flexible Purpose Corporation," the "Low-Profit Limited Liability Company," and the "Benefit Corporation."

\section{The Flexible Purpose Corporation}

The Flexible Purpose Corporation (FPC) was introduced in California in early 2010 as Senate Bill 1463. ${ }^{332}$ The central feature of an FPC is a requirement that its articles of incorporation "identify at least one special purpose to be considered in determining the best interest of the corporation and its shareholders." 333 In focusing on a "second 'bottom line," in addition to "shareholders' financial interest," the directors "will be shielded from potential personal liability for breach of fiduciary duty." 334 This protection goes to the heart of the problem the law's drafters sought to address-allowing the FPC's directors to pursue the FPC's explicitly stated public purpose, even if doing so negatively impacts shareholder wealth. ${ }^{335}$

Although Senate Bill 1463 did not survive, it was reintroduced as Senate Bill 2011 in February 2011.336 It was subsequently enacted in October 2011 and became effective on January 1, 2012.337 In view of its recent arrival on the scene, the FPC's effectiveness in accomplishing its intended objective remains to be seen.

331 See supra Section IV(B).

332 Clarke, supra note 6, at 318 (citing S.B. 1463, 2010 Leg., Reg. Sess. (Cal. 2010) at 1).

333 Id.

334 Id. at 318 \& n. 168.

335 See id. at 319.

336 Id. at 321.

337 See California Flexible Purpose and Benefit Corporations, California Business LAW Blog: LAW Office OF JonAs M. GRAnt, A.P.C. (Jan. 1, 2012), archived at http://perma.cc/ZHW3-FFMK. 


\section{The Low-Profit Limited Liability Company (L3C)}

The L3C is not a corporation, as are the FPC and the Benefit Corporation, but rather is a form of Limited Liability Company (LLC). ${ }^{338}$ The concept was introduced in 2005 by Robert Lang, "in an effort to increase and diversify capital of organizations pursuing a socially beneficial purpose." ${ }^{339}$ It is considered a nonprofit/for-profit hybrid and has been referred to as "a 'for-profit entity with a nonprofit soul." 340 Generally speaking, an L3C is required to satisfy three criteria: "(1) it is required to significantly further a 'charitable' purpose as defined under the tax law; (2) its significant purposes may not include producing income or appreciating property; and (3) it may not conduct lobbying or political campaign activities." 341 As a new form of legal entity, the L3C was first recognized in Vermont in 2008. ${ }^{342}$

An L3C has a narrower objective than other forms of hybrid legal structures-"to attract capital from "private foundations' 343 for socially beneficial purposes." ${ }^{444}$ That is, private foundation giving for "program related investments" (PRIs) is often discouraged by complex tax requirements that are expensive and time-consuming to meet. ${ }^{345}$ L3Cs were designed to facilitate compliance with these requirements by incorporating them directly into the entity's actual legal framework, eliminating (hopefully) the foundation's need to obtain a legal opinion or IRS approval

338 See Clarke, supra note 6 , at 321.

339 Id. at 311. "Lang is the CEO of The Mary Elizabeth and Gordon B. Mannweiler Foundation." Id. at n.97.

340 Id. at n.67.

${ }^{341}$ Lofft et al., supra note 4, at 11 (citation omitted).

342 Id. at 10.

343 Id. "A private foundation is a specific type of tax-exempt organization that functions generally to make grants to other charitable organizations, like hospitals. The tax law permits private foundations to make certain investments in for-profit ventures that benefit the public and that are generally too risky or provide too low return to entice private investors, known as 'program related investments' or 'PRIs."' Id. (citing I.R.C. § 4944 (1986)).

${ }^{344}$ Lofft, et al., supra note 4, at 10.

345 Id. 
in advance. ${ }^{346}$ However, because the IRS has yet to officially determine the effectiveness of L3Cs in meeting this goal, it remains unclear whether they offer any significant new advantages for PRIs. ${ }^{347}$ As of 2013, the L3C was recognized in no more than nine states, with a few others having pending legislation. ${ }^{348}$

\section{The Benefit Corporation}

The Benefit Corporation began as a "project of the nonprofit organization B Lab." ${ }_{49}$ A white paper discussing the need and rationale for model legislation (and containing the model legislation itself) was drafted by principal authors William H. Clark, Jr., of Drinker, Biddle, \& Reath LLP and Larry Vranka of Canonchet Group LLC. 350 Kanig provides an excellent, concise summary of this hybrid legal structure:

Benefit corporations are dual purpose, blended entities, adhering to the mold of Dodd's social enterprise theory and the social entrepreneurship movement, with a legal structure that embraces both the pursuit of profit and the material enhancement of the public good. This general legal structure provides a benefit corporation with two distinct advantages over non-profits and traditional corporate entities. First, unlike non-profits, the board of directors may issue dividend payments to shareholders. Escaping the non-

\footnotetext{
346 See id. at 10-11.

347 See id. at 11.

348 Id.

349 Kanig, supra note 8, at 891 (citing The Non-Profit Behind B Corps, B CORPORATION, http://www.bcorporation.net/what-are-bcorps/the-non-profit-behind-b-corps (last visited Jan. 4, 2014)).

350 William H. Clark \& Larry Vranka, The NEED AND RATIONALE FOR THE BENEFIT CORPORATION: WHY IT IS THE LEGAL FORM THAT BEST AdDREsses the NeEds of Social Entrepreneurs, InVEstors, AND, Ultimately, THE PUBLiC (2013), available at: http://www.benefitcorp.net/storage/documents/Benecit_Corporation_Whi te_Paper_1_18_2013.pdf.
} 
distribution constraint is essential to accessing sufficient financing to compete with traditional corporate entities, while also attracting management talent who desire wealth. Second, the benefit corporation also possesses an affirmative statutory mandate to pursue the general public benefit, in addition to any specific public benefits included within the articles of incorporation. This enables benefit corporations to transcend the efforts of corporate social responsibility because they are manifestly enabled to construct positive externalities. The express statutory purpose of the benefit corporation is to distance itself from the shareholder wealth maximization norm that has dominated traditional corporations, to increase transparency in corporate decisionmaking, and to increase accountability for promised social outcomes. ${ }^{351}$

Benefit Corporations are said to "remove any lingering doubt left by constituency statutes" regarding director' liability by protecting directors' decision-making in both "the ordinary course of business and in the context of takeovers." 352 Of perhaps most significance, Benefit Corporations provide "a framework for "mission accountability' - that is, for monitoring and enforcing [their] effective pursuit of their public interest mission." 353 This new corporate form has been described by some as "an entirely new 'fourth sector,' joining the ranks of the 'big three' sectors of government, business and nonprofits" 354 Others describe it as "a convergence of the three." 355

As of 2013, twelve states had enacted enabling legislation for Benefit Corporations, with fourteen

351 Kanig, supra note 8, at 891-892 (emphasis added).

352 Cummings, supra note 317 , at 590.

$353 \mathrm{Id}$.

${ }^{354}$ Cummings, supra note 317, at 582 (citing See David J. Siegel, The Promise of Intersectoral Collaboration, in Organizing for Social Partnership 47, 50-51 (2010) (describing "big three" sectors)).

355 Id. 
additional states having introduced legislation to do so. ${ }^{356}$ In most of these states, as well as under the model legislation, Benefit Corporations are characterized by three principal features:

(1) The corporation is required to provide a "general public benefit;"

(2) the directors' fiduciary responsibilities are expanded to include affirmative consideration and pursuit of articulated general and specific purposes beyond simply maximizing shareholder value, and immunity from liability is provided for doing so; and,

(3) the corporation is required "to report on its overall social and environmental performance as assessed by a recognized third-party standard that is comprehensive, credible, independent, and transparent." 357

In addition to the reporting requirement described above, most Benefit Corporation statutes provide a "benefit enforcement proceeding" that allows minority directors and shareholders to bring legal action against the corporation and its majority directors for:

- "a failure to pursue the general, or any specific, public benefit purpose of the benefit corporation;"

- a director's violation of an imposed standard of conduct or duty; and/or,

- "a failure to deliver or post the annual benefit report." 358

However, because "[t]he true strength of the benefit corporation ... lies in enforcing . . . the non-shareholder

356 Lofft, et al., supra note 4, at 10 (citing Benefit Corp Information Center, BENEFITCORP, http://www.benefitcorp.net/.

357 Id.

358 See Kanig, supra note 8, at 895. 
interests imposed . . . by the statutes," 359 these enforcement provisions have been criticized for not providing standing to "third-party beneficiaries" (i.e., "non-corporate actors") who may well include stakeholders with a significant interest in the corporation's general or specific public benefit $\operatorname{purpose}(\mathrm{s}) .360$

The tax status of the Benefit Corporation remains an open question. While the FPC "is essentially a for-profit corporation," 361 the Benefit Corporation, like the L3C, is "skewed to the side of public benefit rather than profitmaking."362 Nonetheless, despite its arguable advantages in accomplishing both general and specific public benefits, "[t]here are, as yet, no material tax advantages to organizing as a benefit corporation ...."363 This may be due in part to the absence of case law in such a newly developing area, and in part to the absence of developed standards for "balancing" the corporation's public benefit purposes against both each other and the traditional objective of generating some level of profit. ${ }^{364}$

Uncertainties notwithstanding, Lofft et al. believe that this hybrid organization offers "some promise in helping bridge the gap that exists between the historic [binary] approach to business structuring in the United States and the reality of the health care market and health care delivery as it exists today." 365 The "forces of change" in health care generally, and the new imperatives of the ACA specifically, clearly will:

require providers to make substantial upfront investments in new programs, systems, technologies and/or equipment that will deliver efficiencies, improve quality and maximize value over the longer term. They may also

359 See id. at 897.

360 See id. at 896.

361 Clarke, supra note 6 , at 327.

362 Id.

363 See Lofft, et al., supra note 4, at 10.

364 See id.

365 See id. at 9. 
require various parties, including insurers, providers, vendors and others, to come together and find new and innovative ways to collaborate and/or integrate-to share knowledge, data and best practices to achieve these objectives. It would seem clear that efforts directed towards improving healthcare quality and maximizing value would have a significant public benefit typical of the public and nonprofit sectors. Such efforts and initiatives, however, may require or at least benefit from the involvement, institutional knowledge and capital raising potential of the private sector. ${ }^{366}$

\section{The Fiduciary Medicine Model}

Finally, a recurrent theme throughout this article has been the idea of accountability. Accountability is "an obligation or willingness to accept responsibility or to account for one's actions." 367 The idea is repeatedly found in discussions of the obligations of corporate governance, regardless of corporate form. The relevant point is this: "[f]iduciary law, embodied in common law duties, statutory standards, and equitable principles, is the primary legal mechanism for assuring accountability in American corporations." 368 In this context, "[f]iduciaries are those undertaking a duty to act for the benefit of others as to matters within the scope of their fiduciary relationship:" 369 for-profit directors have a fiduciary obligation to maximize shareholder wealth; charitable nonprofit directors have a fiduciary obligation to use the corporation's assets for the benefit of the community.

In health care, the doctor-patient relationship has long

366 See id. (emphasis added).

367 See MERRIAM-WEBSTER ONLINE Dictionary, Accountability, http://www.merriamwebster.com/dictionary/accountability ?show $=0 \& \mathrm{t}$ $=1385478126$.

368 Greaney \& Boozang, supra note 54, at 33 (emphasis added).

369 Id. at n.127. 
been recognized as embodying the epitome of fiduciary obligation. This fiduciary obligation derives from "the trust and confidence patients place in physicians to operate in good faith, remain loyal to their patients, and subordinate their own self-interest and the interests of others." 370 Moreover, the centrality of this idea in health care reform is obvious-it is imbedded in one of the principal proposed reform mechanisms, the "Accountable Care Organization." Indeed, the very name suggests that this new, integrated, coordinated-care organization itself has a fiduciary obligation to the patients it serves comparable to that historically attributed only to physicians. As Rodwin has said: "Public policy and market forces are creating pressures for greater physician and provider accountability. And accountability is the core of the fiduciary ideal." 371 This, then, is essentially the "Fiduciary Medicine Model" proposed by Dayna B. Matthew, Vice Dean and Professor of Law at the University of Colorado Law School. ${ }^{372}$

Matthew's model embodies a new legal paradigm that she asserts is best suited to "implementing and achieving the goals of the ACA"- "to universalize access to health care," while reshaping the private and public financing markets "and the organizational entities that deliver and control the quality" of health care services. ${ }^{373}$ The basic idea is to extend those fiduciary obligations (i.e., good faith, loyalty, and due care) that are already well-established in the profession of medicine "to all major participants in the health care industry" who are involved in the direct delivery of health care services to patients. ${ }^{374}$ Such extension is justified by the changes in health care delivery brought about by the development of the "medical industrial complex" and the reality of "new, larger, and more interdependent actors in that medical complex,"

370 Matthew, supra note 7 , at 726.

371 Id. at 737 (citing Marc A. Rodwin, Strains in the Fiduciary Metaphor: Divided Physician Loyalties and Obligations in a Changing Health Care System, 21 AM. J.L. \& MED. 241, 255 (1995)).

372 See generally id.

373 See id. at 718.

374 See id. at 718, 761. 
increasingly engaged in "group-based decision-making" under the new imperatives of the ACA. 375

\section{Conclusions}

One [question] is whether there is some quality that comes with the nonprofit form that is essential to the field of health care-mission, voluntarism, or something else. In other words, is there something about health care that makes the nonprofit or public form somehow more morally appropriate than the for-profit or investor-owned form? Or is an institution's tax status just a means to cope with its environment? But the argument about the rightness or wrongness of entrepreneurial trends is not the only place for us to focus. We should also consider the possibility that the change that is occurring will not reverse. If that is the case, then a real challenge for those interested in health policy is how to assure that the entrepreneurial forces move in directions that will serve the goal of health care for people and that will avoid some of the dangers that we can all recognize are present. ${ }^{376}$

The deontological status of health care in the United States today lies somewhere between a "public good" and a "right." It is clear that the ACA-by advancing a scheme to provide near-universal access to insurance coverage-is moving the delivery system closer to the "right" end of the continuum. It is equally clear that a significant percentage of the body politic will never subscribe to the idea of health care as a direct, government-provided entitlement. Clearly, it was recognition of this fact that led to the compromise position taken by the ACA-that Americans do have a right to receive health care, but in a free, competitive

375 See id. at 742-743.

376 Gray, supra note 101, at 21-22. 
marketplace with a corresponding obligation to pay for it.

This obligation to pay for health care departs significantly from the historical tradition of the charitable, nonprofit hospital - a tradition arising from a bygone era when the country's health care needs could be met wholly through charitable care-giving, institutional or otherwise. Such era ended when health care became commercialized as a result of knowledge and technology that exponentially expanded both the complexity and cost of health care services. Health care today constitutes a mature "industrial sector," consisting of a heterogeneous web of participants that includes nonprofit and for-profit service-providers, as well as innumerable sector-supporters. The web is diffuse and disparate, reflecting a high degree of specialization and comprising $17 \%$ of the nation's economy. It is also unwieldy and dysfunctional, and plagued with unintended consequences and counterproductive incentives. The oftensensationalized wayward behavior of some tax-exempt, nonprofit hospitals is but one example of this dysfunction.

Bad behavior by such hospitals results from misguided efforts to balance the tension between "mission and margin" inherent in the nonprofit form. As Senator Grassley's crusade well demonstrates, too many nonprofits have responded to their increasingly competitive, commercialized environment by over-emphasizing margin at the expense of their charitable mission. The traditional threat of losing their tax-exemption has not been an effective deterrent to such conduct. However, to the extent that the ACA further reduces the need for charity care by providing broader insurance coverage, the more irrelevant the nonprofits' traditional mission becomes. It is far from clear, moreover, that the ACA's new community benefit requirements will serve to re-equalize the quid pro quo, further drawing into question the more than $\$ 12$ billion dollars that nonprofit tax-exemptions cost in foregone governmental revenue.

In attempting to address other delivery system dysfunctions, the ACA's new imperatives will further challenge the historical, limited "binary" choice between nonprofit and for-profit organizational forms. That is, the "integrated and coordinated care model" envisioned by the 
ACA necessarily will require additional industry consolidation, increased access to capital, closer collaboration between and among system participants, and greater accountability for quality and high-value outcomes. It is for all of these reasons that a new organizational paradigm is here suggested-a specific form of Benefit Corporation (i.e., a "Health Care Benefit Corporation" (HCBC)) expressly designed for health care delivery and predicated upon the concept of mission primacy and the Fiduciary Medicine Model. As a practical matter, the HCBC would be an adjunct to, rather than replacement for, existing nonprofit and for-profit organizations-arguably most appropriate for multi-stakeholder arrangements such as ACOs.

While a complete explication of such a new conceptual entity is beyond this article's scope, its essential features and advantages can be described. ${ }^{377}$ First, like all Benefit Corporations, the HCBC would be a blended, dual-purpose entity having a legal structure that serves to pursue the public good together with profit seeking as the explicit and legally enforceable mission of a single business enterprise. The "public good" in this instance would be unequivocally identified in the corporation's articles of incorporation as the ongoing and consistent provision of affordable, highquality, high-value, and readily accessible health care services. This would be the organization's primary mission, which the governing directors and management would (for the first time) have a legally enforceable fiduciary duty to pursue. Second, the HCBC would have a subordinate mission of targeted profit seeking and distribution, intended to attract equity investors and management talent, as well as provide access to taxable capital markets. This feature would better facilitate the integration/coordination of the multiple stakeholders needed for successful ACO development by, among other things, eliminating the private inurement constraint. Third, the organization would receive a modified level of tax benefits appropriate for

377 Needless to say, all of these suggested features and characteristics would require the approval of the IRS and other relevant regulators. 
its explicitly defined dual mission and more in keeping with the reduced need for charity care expected under the ACA. This might, for example, include access to tax-exempt debt markets, as well as continued tax deductions to donors for charitable donations to the $\mathrm{HCBC}$ and to the $\mathrm{HCBC}$ itself for providing actual "free" care to qualified indigents; but, elimination of "tax-arbitrage" by the HCBC and income (both state and federal), property, sales, and related tax exemptions for the HCBC.

It is, perhaps, an idea worth considering. 
